Historic, Archive Document

Do not assume content reflects current scientific knowledge, policies, or practices. 



\section{Knipht's Guide}

Small Fruits

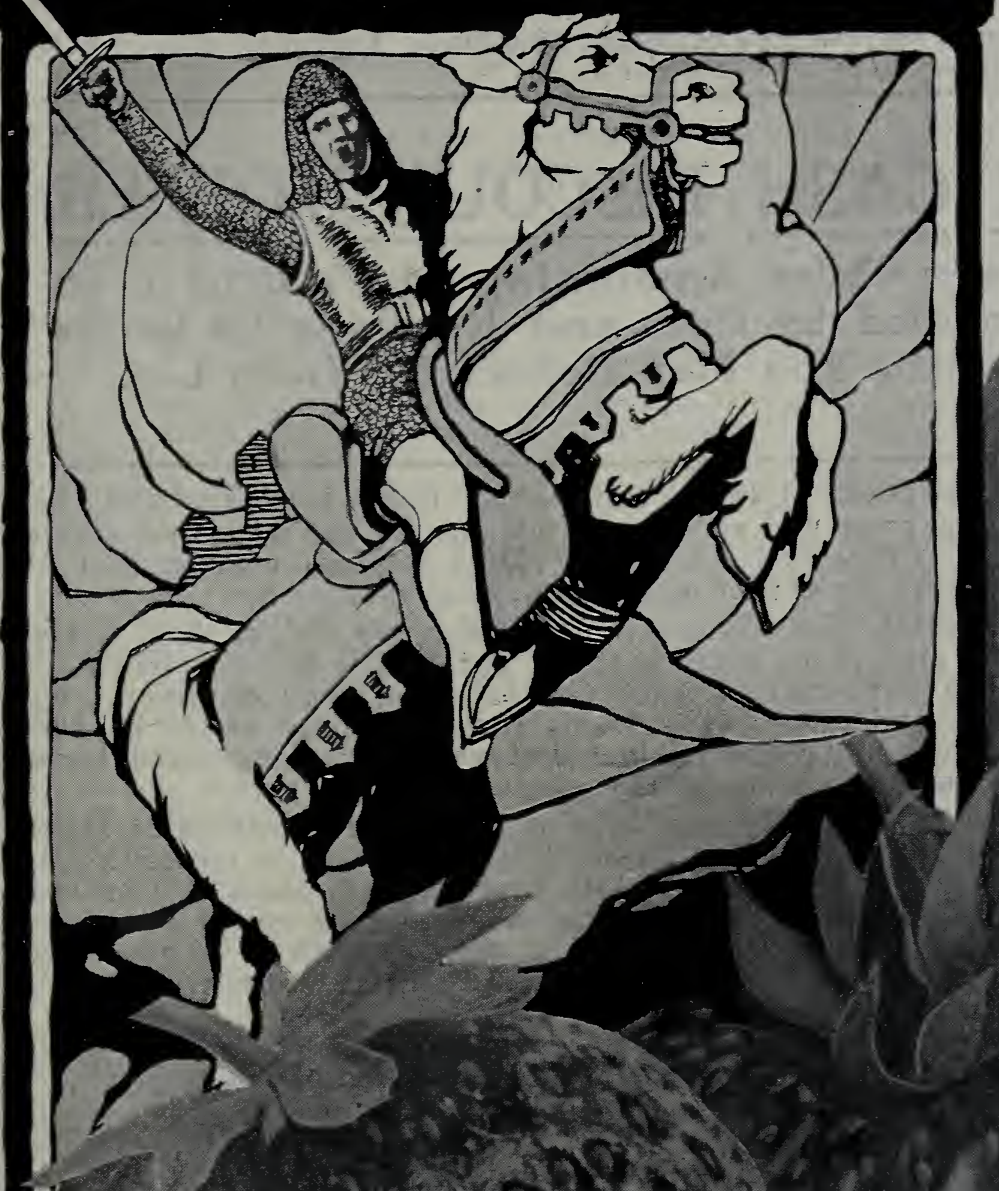




\section{HOW WE DO BUSINESS}

Post Office, Express Office and Telegraph Office at Sawyer, Michigan. Bell Telephone in our office.

TERMS. Cash with order, or part cash when order is sent, the balance to be sent before shipment.

REMITTANCES. Send money by Check, Draft, Post-Office Money Order, Express Money Order, or Registered Mail. Currency sent in a letter without registering is at sender's risk.

\section{OUR CASH DISCOUNT OFFER For Every Order Amounting to $\$ 5.00$ or over, Accompanied by Cash and Reaching Us before March 15th, You May Deduct 5\% from List.}

HOW TO ORDER. Use the order sheet found in this catalog, being sure to write your name and address plainly, and fill out all blanks carefully with reference to where you want your plants shipped, whether you want them sent by express, freight, or mail, and at what time.

HOW WE SHIP. Express is much the safer way and, as there is a general special rate applied to nursery stock, the cost is not exorbitant. We guarantee express shipments to reach destination in good condition. Raspberry, blackberry, and other heavy plants can be shipped safely by freight early in the season and considerable transportation charges saved thereby. However, all freight shipments go at consignee's risk.

PARCELS POST. Plants may be sent by mail at a reasonable expense. For instance, 100 strawberry plants can be sent anywhere in the 1st zone for about 7c; 2nd zone, 7c; 3rd zone, 10c; 4th zone, 15c; 5 th zone, 20c; 6 th, zone, 25c; 7th zone, 31c; 8th zone, 36c. We cannot give you a very close estimate on raspberry and blackberry plants as they vary so much in weight. Plants may be sent C. O. D., both for cost of plants and postage. However, this costs you more for return of money.

ORDER EARLY. Do not delay placing your orders until you are ready to plant. The earlier orders are placed, the better it is for you and for us. All orders are booked in rotation as received, therefore it is to your advantage to get your order placed early before varieties you wish are gone.

GUARANTEE. We are careful to label, count, and pack our plants correctly, and we assume the responsibility of replacing, free of charge, any stock sent by us that proves untrue to label or short in count; however, it is understood between the purchaser and ourselves that we are not to be held liable for any greater sum than that paid for such stock as may prove untrue to label.

COMPLAINTS. Complaints, if any, must be made within ten days after receipt of stock.

SHIPPING SEASON. Commences about March 15 and continues until about May 15.

\section{CERTIFICATE OF NURSERY INSPECTION No. 2217}

This is to certify that I have examined the nursery stock of David Knight \& Son, Sawyer, Mich., and find it apparently free from dangerous insects and dangerously contagious tree and plant diseases.

This certificate to be void after July 31, 1921.

$$
\text { L. R. TAFT, }
$$

State Inspector of Nurseries and Orchards, Agricultural College, Michigan, October 16, 1920. 


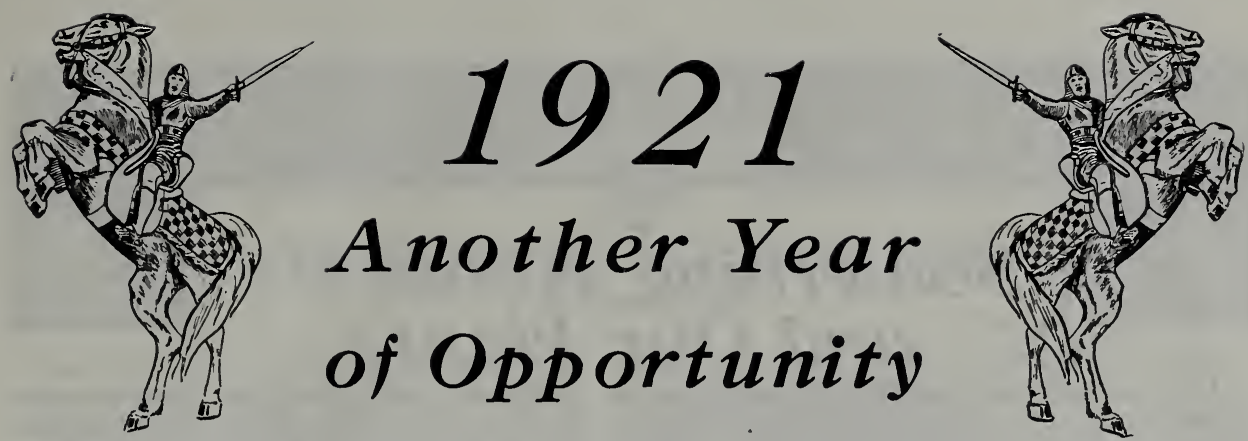

Within the past few years berry growers have built more homes, have been able to buy more comforts and luxuries for those homes, have paid off more mortgages and have become a better satisfied and more contented class of people than those engaged in any other branch of farming.

Last summer was another wonderful season for the small fruit farmer. With prices the highest ever known, and a full crop, why shouldn't he be smiling and happy? Why, we have seen income tax reports-with good sized checks accompanying them-sent in by small fruit farmers who have only ten and twenty acres of land and who, a few years ago, were wondering where the money was coming from to pay their taxes and interest.

And the opportunity is still with us. The price of all small fruits will be high for years to come for, with greatly improved marketing facilities, with a constantly increasing demand for fruit and with the canners always in the market buying heavily and at good prices, we need not fear that berries will ever be so cheap that it will not payand pay big-to grow them.

Just compare the prices that berry growers received for their fruit last season with the low prices that apples and pears had to be sold for. Also compare those same herry farmer's returns with what the grain farmer received for his wheat, corn and oats. Then you will know, as we do, that it is more profitable to grow 10 acres of berries than 80 acres of nearly any other crop.

Our thirty-five years in the plant business is your assurance that you are taking the first step in the right direction by placing your order with us. You undoubtedly have a neighbor who has used our stock and will tell you of its superiority, for we have thousands of satisfied customers all over the United States who are always glad to speak a good word for us and our plants. In fact our large business has been largely built up by the word being passed along from our customers to their friends that "Knight's plants are good plants," as we have done no extensive newspaper advertising and have thus been able to sell the best plants obtainable at a price that our customers could afford to pay.

Our supply of plants this year is large, and quality excellent, but the demand is so very heavy that we anticipate being sold out early. Don't make the mistake of waiting until planting time before placing your order. The one sure way of getting the varieties and quantities you want is to make up your order and send to us as soon as this book reaches you.

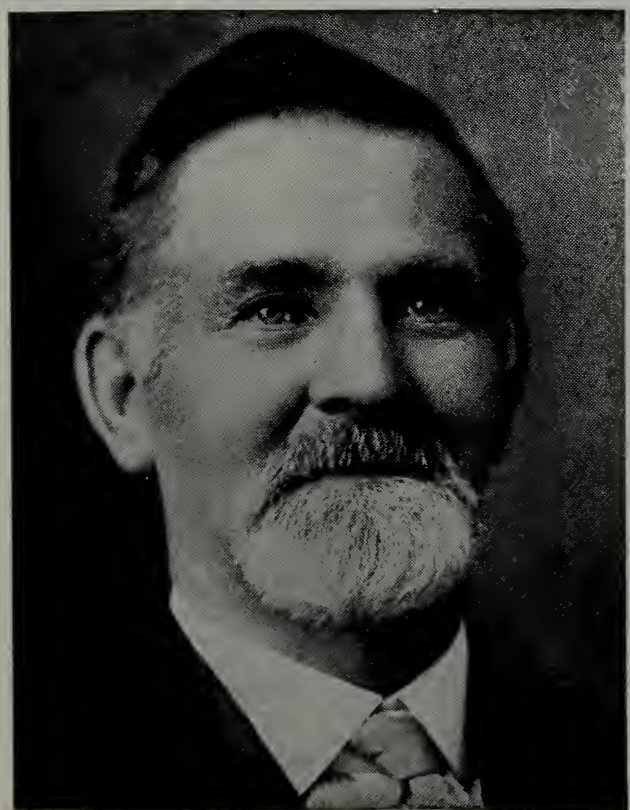

David Knight.

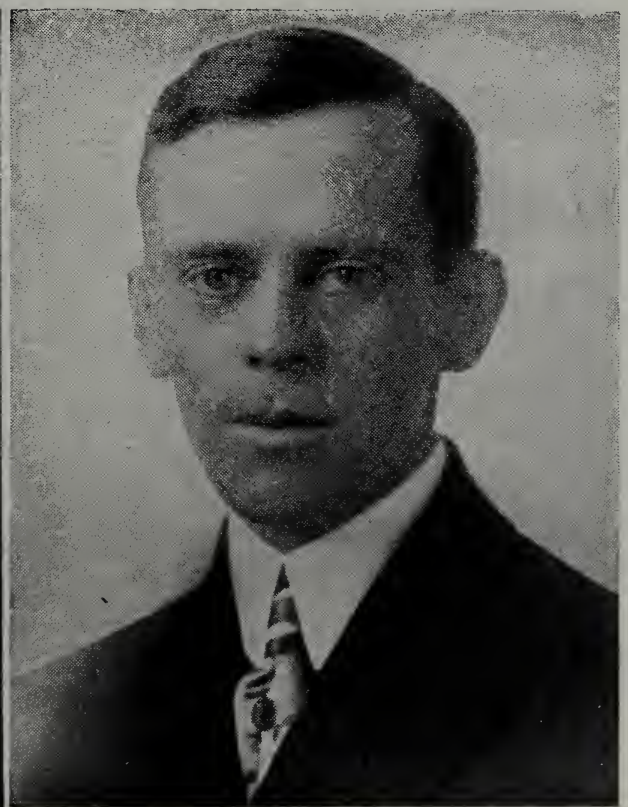

A. R. Knight. 


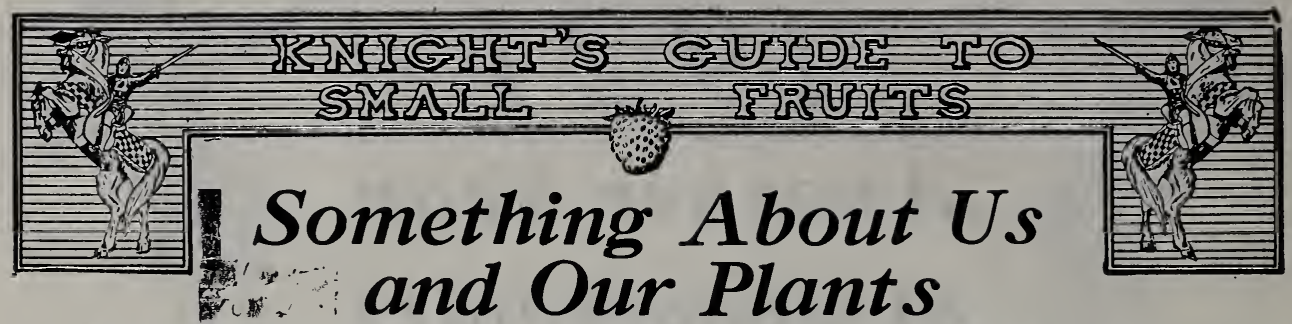

A saving of 50 cents or $\$ 1.00$ per thousand on small fruit plants is mighty poor economy if, by doing so, you sacrifice quality. The cost of enough plants to set an acre of berries is very small when compared to the expense of getting your land in shape and caring for the patch until it produces fruit. It is therefore most essential to get the very best plants obtainable, regardless of cost, for by not doing so you stand a good chance of not only losing the inital cost of the plants but also your labor for a year and the use of your land for that length of time.

You naturally ask, "Who has the best plants, I receive fifteen or twenty catalogs every year and they all claim their stock is superior, so how am I to know where to buy?" Well, the answer isn't easy, but we want to tell you a few reasons why we believe your interests will be best served by using KNIGHT'S plants.

In the spring of 1885 our first catalog was mailed. It was simply a folder describing Just one variety, the old Wilson's Albany strawberry. Only two hundred copies were sent out and, naturally, our business was very small. However, every year since, Knight's catalog, in gradually larger size and larger quantity has been mailed to a continually enlarging number of customers, until at present we ship millions of plants every season to patrons in nearly every State in the Union.

Our business having grown from practically nothing in 1885 to one of the largest of its kind in the country today is an assurance that we know the plant business well and that we have always had the interest of our customers at heart for, were this not true, our career as nurserymen would have been ended years ago. It is your assurance that an order placed with us will bring you good, strong, true-to-name plants, the kind that will surely produce a productive fruiting patch for you.

Glowing, over-drawn descriptions, catch phrases, and possibly lower prices may attract you, but why take a chance when KNIGHT'S fruit plants have made so much money for thousands of fruit growers throughout the whole country and will just as surely be profitable for you.

The plants which we use in setting our new patches are those selected with great care so that no weak or imperfect plants will be the mother-plants to the stock sent our customers.

Our strawberry patches are set in the spring, make their growth of runners and new

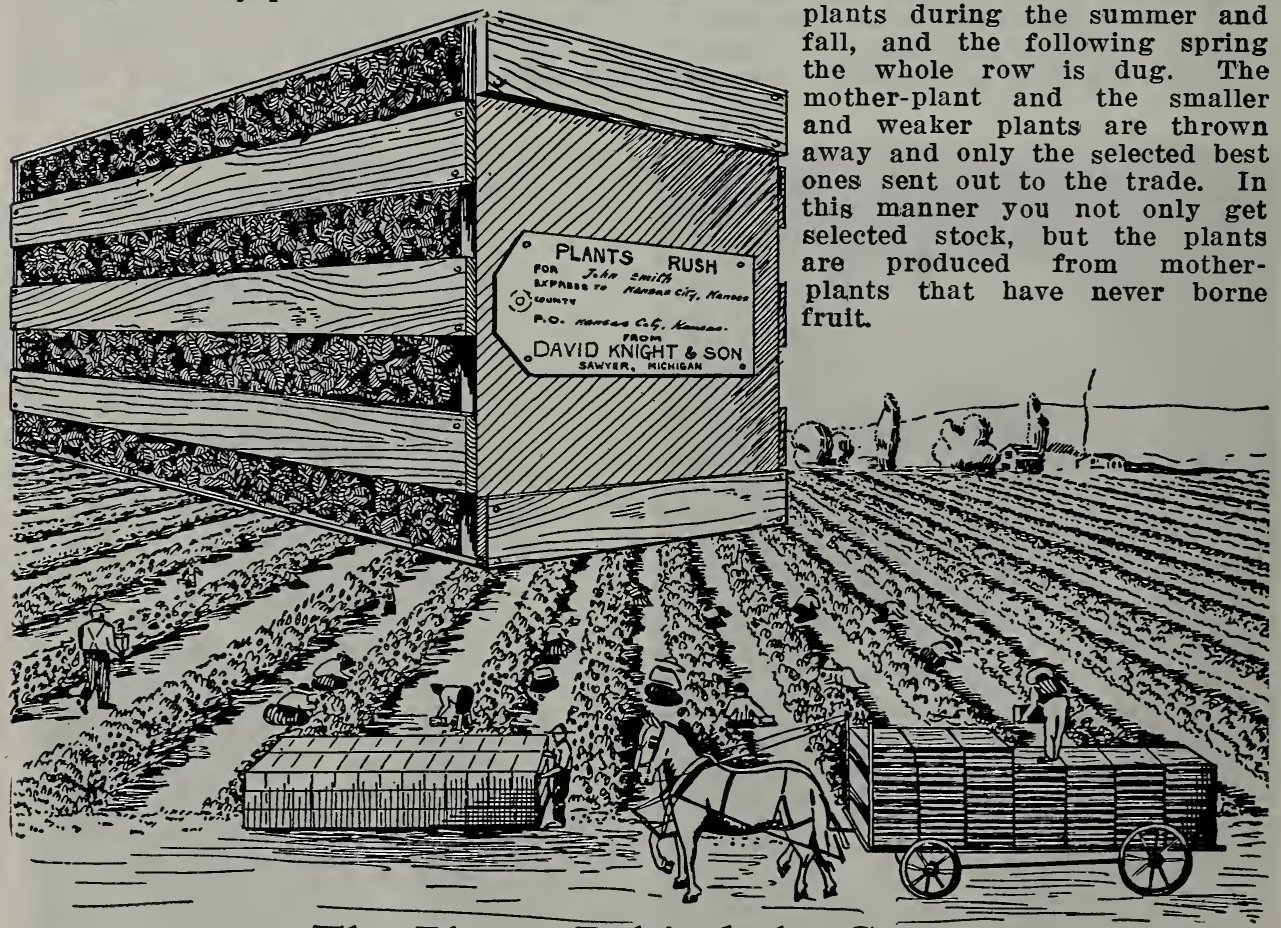

The Plants Behind the Crop. 


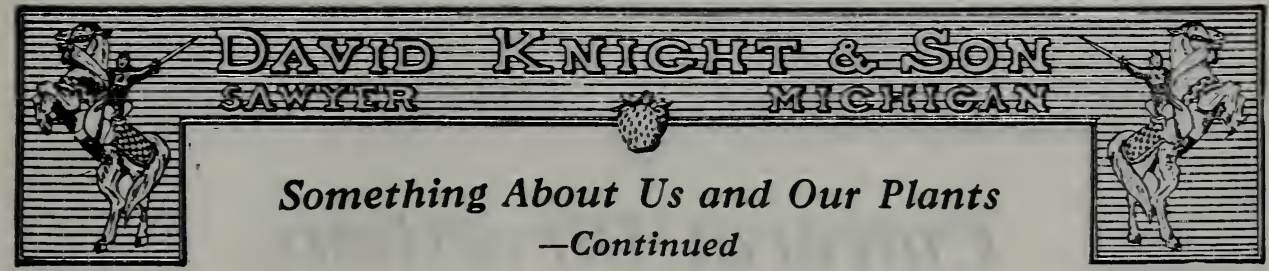

Our black raspberry plants are obtained by tipping down the canes of young patches. These are called "tlp plants" and are illustrated at the bottom of this page. Note the strong fibrous roots. Also these tip plants are planted and grown for a season and then are called "transplants." Don't fail to read about them on pages 20 and 21.

The enormous root system of all of our plants is a surprise and delight to our thousands of customers-Just note the strawberry plants at the bottom of this page. Such fine flbrous plants cannot help but grow if properly packed so as to reach you in good condition and our many years experience has taught us how to pack stock so it will arrive in the very best state of preservation, regardless of the distance. The illustration on this page shows how some of our plants are packed.

Only the very best selected plants of strawberries, raspberries, blackberries and other small fruits are packed and shipped from our nursery and, we repeat, you cannot afford to buy plants of any firm or at any price, that have not been grown and selected with as much care as we exercise here at Sawyer.

That it pays to grow small fruits is an established fact, but if you wish to get the most for your labor you should be sure that the plants you use are well

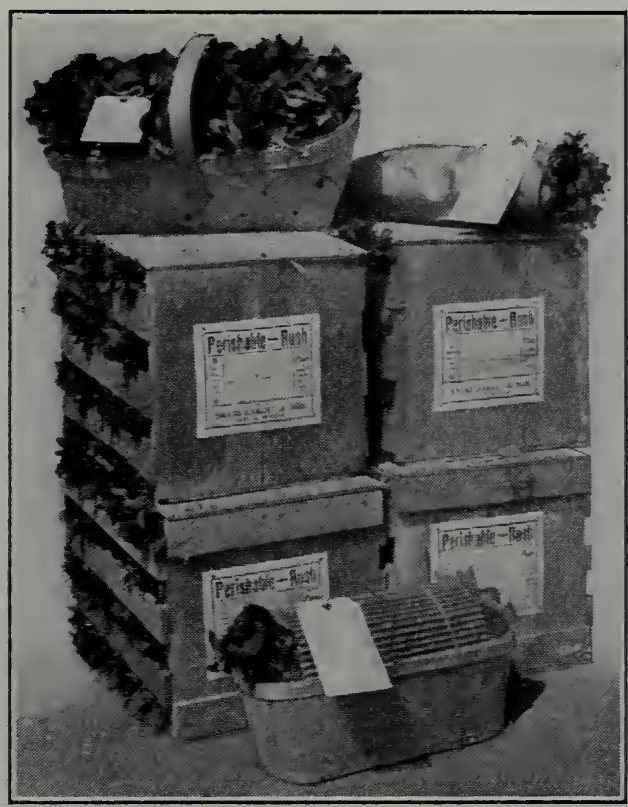

Good packing is rery essential. All of our plants are packed in bundles, baskets and crates, and are sure to reach you in good condition.

grown, strongly rooted, and true to name. You cannot afford to set plants of inferior quality no matter how cheap you can get them. The best is none too good and when you pay for plants you are entitled to good stock and should have it. If your order is placed with us you will receive the same kind of stock that the large growers all orer the country have been using for years and depend upon; stock that has made big money for others and will just as surely make big money for you.

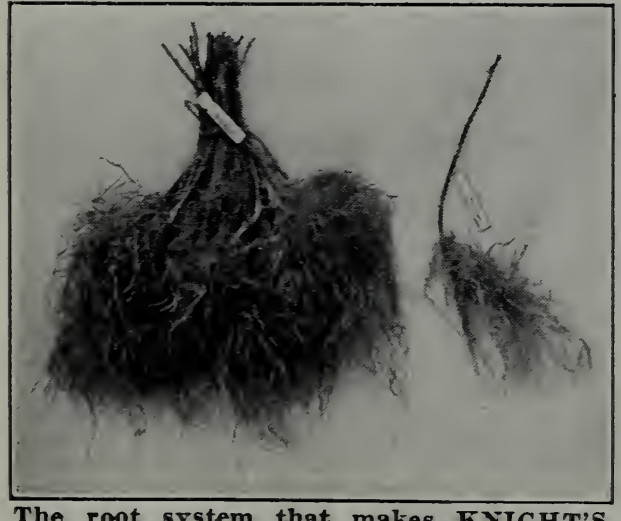

The root system that makes KNIGHT's SMALL-FRUIT PLANTS produce big crops

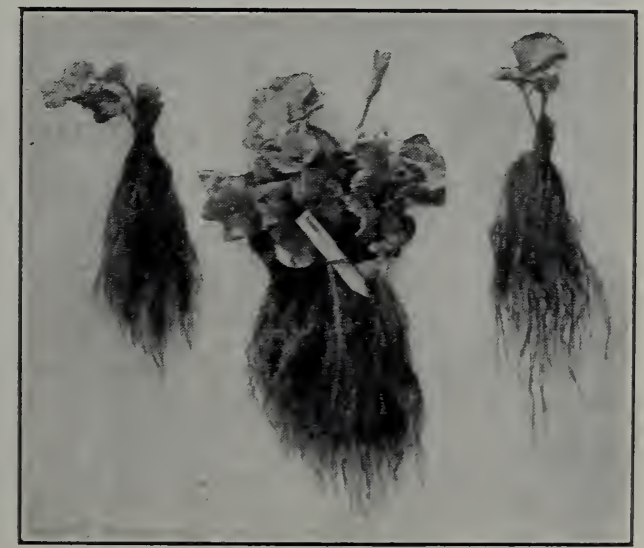

This is the kind of roots KNIGHT'S STRAWBERRY PLANTS develop. 

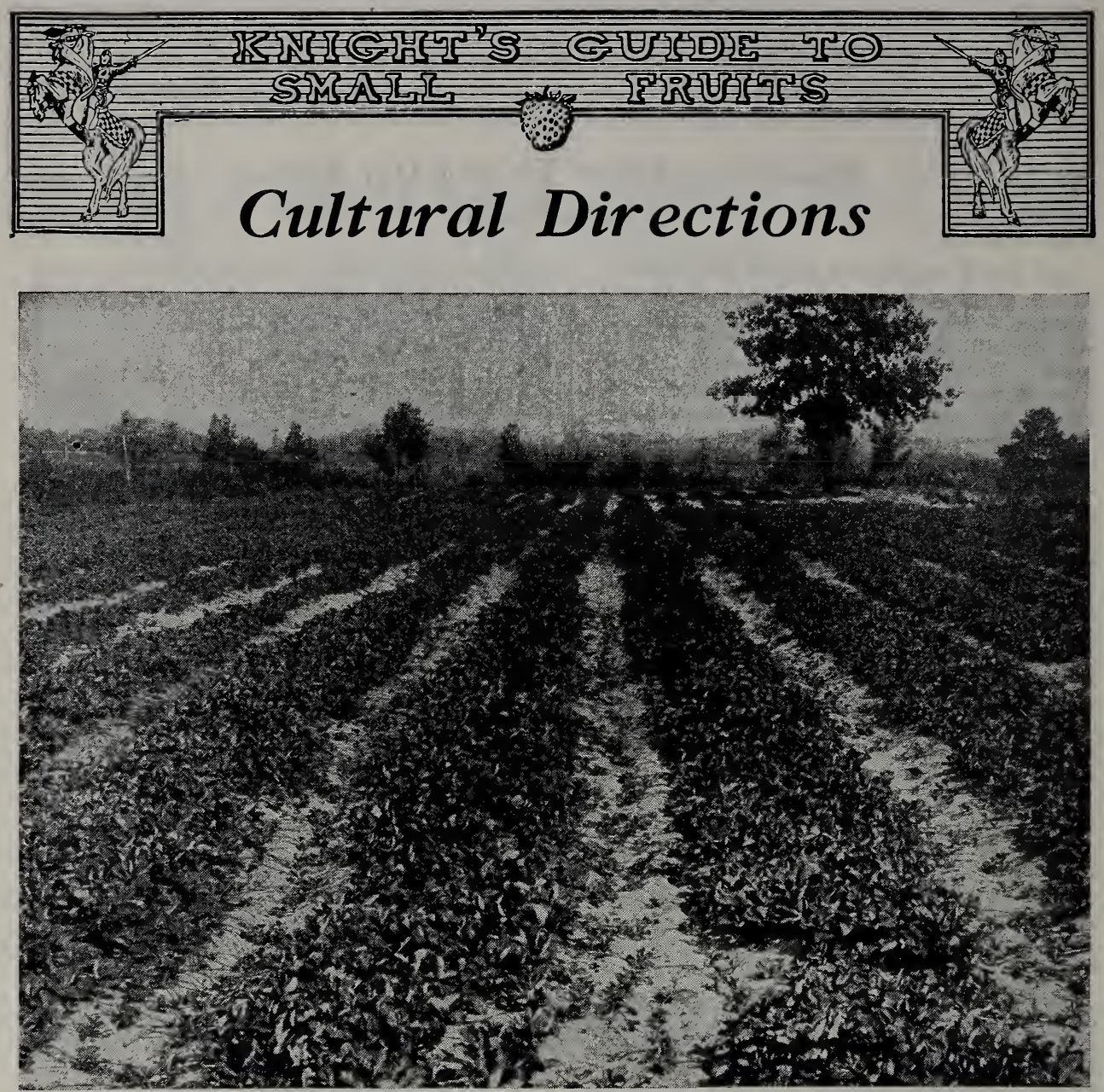

One of our Strawberry patches. Note the strong growth. We have millions of plants like these.

\section{Strawberries}

Strawberries will do well in any soil with exception of very light dry sand and clay that has poor drainage. As moisture is very essential to large crops of fruit, a springy land that is well drained is the ideal soil, but on other kinds of soil the moisture can be conserved by cultivation and mulching.

\section{Preparing the Land}

Any soil on which has been previously grown such crops as potatoes, corn, onions, cabbage, etc., is well adapted for strawberries. This is because the land has been well cultivated during most of the growing season and because manure or fertilizer has been used, all of which benefits the strawberry crop following. Leguminous crops such as clover, vetch, etc., are also excellent crops to precede strawberries, as they add nitrogen and humus to the land. Do not select a piece of land for jour strawberry patch that is in sod for it is very liable to be infested with the white grub, which will cut off the young strawberry plants when set. Barnyard manure is the very best fertilizer for strawberries. It is better to apply it in the fall before planting in the spring, but if this has not been attended to, then very good results can be obtained by spreading it on the land as early in the spring as possible and plowing under. After the land is plowed the harrow and disc should be freely used until the soil is mellow and free from clods. In some cases it is advisable to roll the land where it is lumpy and heavy, this also makes the soil firm and helps to conserve moisture. Don't spare any work to put your land in the very best possible condition before planting, for it will save you much cultivation and hard work later on, and the results will more than repay you. 


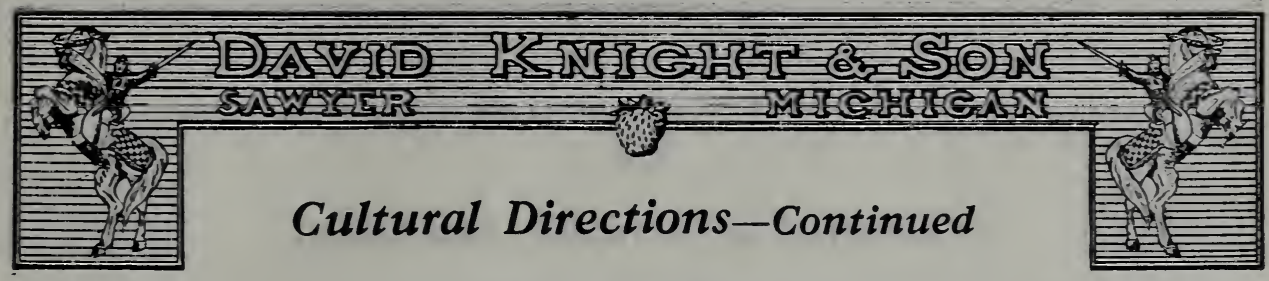

Time to Plant

In the South most of the planting is done in the fall or early winter, but in the Central and Northern States early spring is much the better time, for if plants are set in the fall there is a very short growing season before the ground becomes frozen and the plants, not having become well rooted, are very liable to become damaged during the winter. Get at this work of planting just as soon as you can in the spring. Order your plants shipped from the 1st to 20th of April and if your ground is not in condition when they arrive, heel them in for a few days.

\section{Systems of Planting}

There are sereral srstems of growing strawberries and they all adapt themselves to rarious sections and conditions. Here in Michigan where every farmer grows a large acreage for commercial purposes, the matted row system is used exclusively, but if rou only hare a limited amount of space and if you wish to supply a market that will pay a fancy price for fancy fruit, then use one of the other systems described below.

\section{The Hill System}

With this system the rows should be 30 inches apart and the plants 15 inches apart in the row, thus using about 14,000 plants to the acre. Keep all runners removed. This causes the indiridual plants to become rery large as there is no vitality being used to produce runners and new plants. The ground should be marked off in check rows so that the cultiration one way can be done with a horse and the other way with a hand cultirator. This system requires plenty of manure and fertilizer, also constant attention to cultiration and runner cutting, but the large plants thus established hare a sufficient fruiting surface to produce an enormous crop, and berries grown by the hill system are of unusually good size, quality and appearance.

\section{Twin-Hill System}

The twin-hill system is rery popular where only a limited amount of ground is available, as it utilizes space more economically than the hill system. Mark out two rows 16 inches apart, then leare a space of 30 inches and make two more rows 16 inches apart, and so on. In this way you will have twin rows 16 inches apart and a 30 inch space between each set of twin rows. Set the plants 15 inches apart in the row and have them in check rows so that the 30 inch space can be cultivated with a horse and the 16 inch space and cross cultiration can be done by hand. Keep all runners remored as In the hill system. About 18,200 plants to the acre will be required.

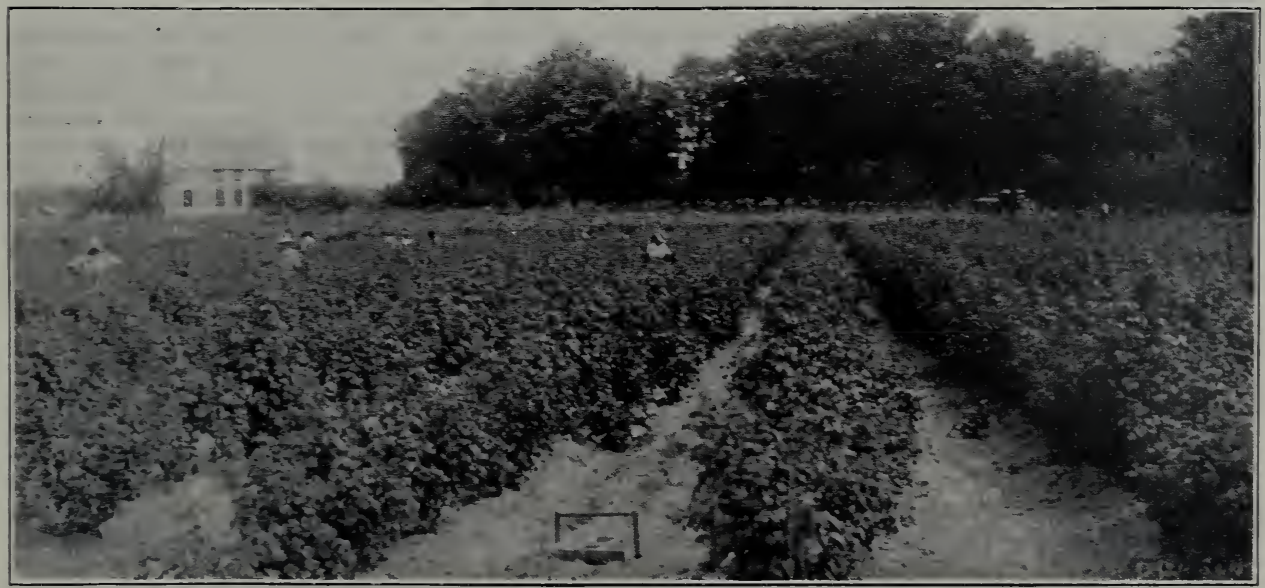

There is Big Money in Raspberries.

One of our customers had net returns last spring of $\$ 1,125$ from less than four acres. You can do as well with Knight's plants. 


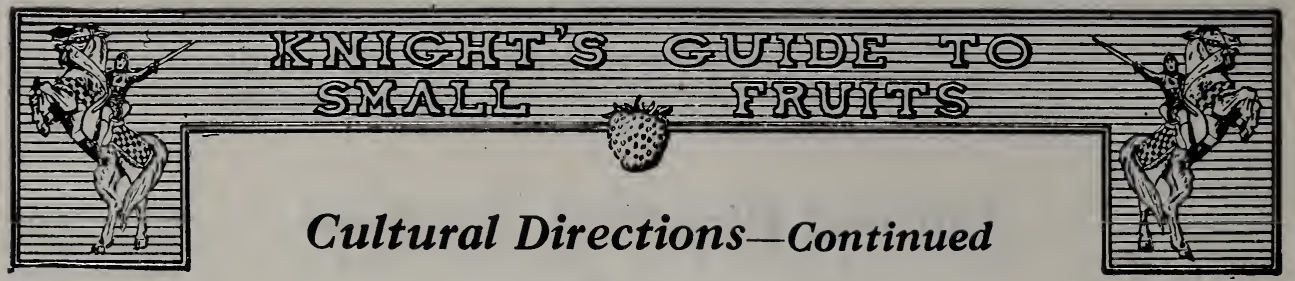

\section{Single Hedgerow}

This is a popular and intensive system of strawberry growing. The plants are set in rows three feet apart, and the plants 2 feet apart in the row. Set in check rows so as to allow cross cultivation. Let each plant produce two runners, and allow only one plant to be formed from each runner, this plant to be placed in direct line with the original row. Clip all other runners and plants as fast as they appear. About 7,300 plants are required to set an acre by this system.

\section{Triple Hedgerow}

This is much the same as the single hedge with exception that 6 runners and plants are allowed to form. Two of these plants are layered in direct line with the original row while two of them are placed on either side of the original row but in line with it, thus when the plants are established there will be three rows instead of one and consequently a larger fruiting surface.

\section{The Matted Row}

This is the most common system of strawberry growing and is very popular where berries are grown in a commercial way on a large scale, as less labor is required in setting and caring for the patch and the quantity of berries produced is usually larger than by the other system. The rows are marked off $3 \frac{1}{2}$ feet apart and the plants set from 18 to 20 inches apart in the row. Let all the runners and plants form that wish to,

\section{HONEYSWEET RASPBERRY HOWARD No. 17 STRAWBERRY \\ The two berry sensa- tions of 1921. Don't fail to get some plants of each this year.}

but when hoeing and cultivating you should keep the rows from 18 to 24 inches in width. The only disadvantage with this system is that sometimes plants set too thickly which results in producing small fruit, but this can be overcome by thinning out some of the plants. There is less work required with the matted row than any other system and, where the rows are kept thinned and not allowed to get too wide, they will produce more fruit and of practically as good size and quality as though grown by the hill system.

\section{Setting Plants}

Your ground should be worked up mellow and free from clods just before planting. After this is done, mark off the ground according to the system of planting you are going to use. A flat dibble or trowel should be used for making the holes, although when two people are working together the spade is a good tool for this purpose as one can go ahead and make holes with the spade while the other follows and places the plants in the holes and firms them in. After pushing the dibble or spade in the ground it should be worked forward and backward a little so as to make the hole large enough for the roots to be straightened out-fanshape-before the dirt is firmed around them. It is very important that the crown of the plant is just at the surface of the ground- not above or below. The roots of the plants should be wet just before setting and it is also a good plan to trim off the roots by about one third.

\section{Cultivation}

Cultivation should commence as soon as the plants are set and continue every ten days or two weeks all during the growing season. This is done not only to destroy weeds but to conserve moisture. After a rain the soil packs down and a baked surface is soon formed which breaks up in large clods, so it is best to get in with the cultivator just as soon after a rain as possible. When a season is severely dry, the cultivator constantly going will form a dust mulch, thus preventing the evaporating of such moisture as remains in the ground and this, in many instances, saves patches that other. wise would be ruined. Proper cultivation has a wonderful effect upon plant growth and anyone who does not attend to this most important part of the work cannot expect to get maximum results. 

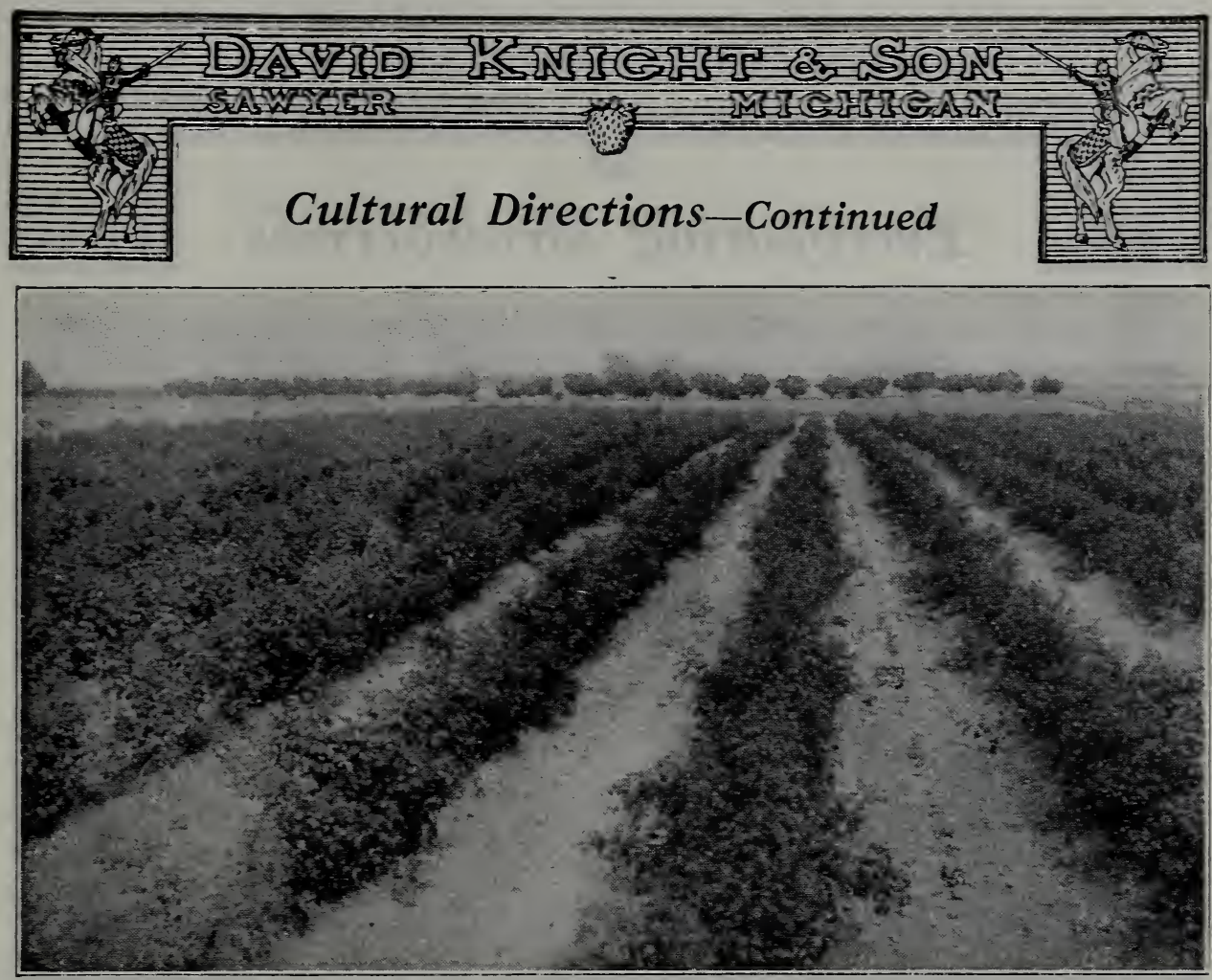

This patch of Raspberries cleared better than $\$ 500$ to the acre last spring.

\section{Care of Patch After Fruiting}

After harresting the first crop of fruit, mow off the foliage with a mower or scrthe. This cleans out the dead leares but does not hurt the cromns. After it is mell dried out rake this rubbish to the space between the roms and burn it. In this way you not only clean your patch and make it easier to work but also destroy all insects and plant diseases. After gettig rid of the foliage it is a good plan to plow a furrow on each side of the row, cutting the bed to about eight or twelve inches. After this is done throw manure into furrows and lerel up with cultirator.

\section{Mulching}

In some sections of the North where a hears fall of snow can be depended upon, patches of stramberries are carried through the winter successfully with no other corering. but as a general rule, it is a good plan to mulch. This should be done after the first hard freeze in the fall. Straw, marsh hay or swamp grass make good mulch, applying about one inch deep over the row and more between the roms. Water from rain and melting snow causes the mulch to pack down tight orer the rines by spring so that the plants are not able to grow through. It is necessary, then, as soon as growth starts in the early spring, to separate the straw directly over the rows so that the plants can grow through. Leare mulch betreen the rows until after the fruiting season as it tends to keep the ground moist. discourages reed growth and keeps the berries clean at picking time.

\section{Perfect and Imperfect Varieties}

In describing the different rarieties of strawberries you will find we hare marked all of them either "Per" or "Imp." The ones marked "Per" produce pollen enough to fertilize themselves and do not need to be grown with other varieties, while those marked "Imp" do not fertilize themselres and when using them erers second or third row should be planted to a perfect blooming rariets.

\section{Heeling-in Plants}

Probably the cause of as much failure as any one thing is the improper handling of plants from the time ther are receired until planted. Vers seldom the shipment of plants arrives on the morning of the day rou had planned to set them, and when they hare to be held orer until sou are ready to plant them then, by all means, heel them in. First dig a $V$-shaped trench, in a shady place, large enough to accommodate the roots without curling them up. Cut the strings that bind the bundles and set the plants in the trench. Draw the earth up over the roots and to the crown, packing it down firmly. Don't neglect to gire the plants a liberal wetting. 

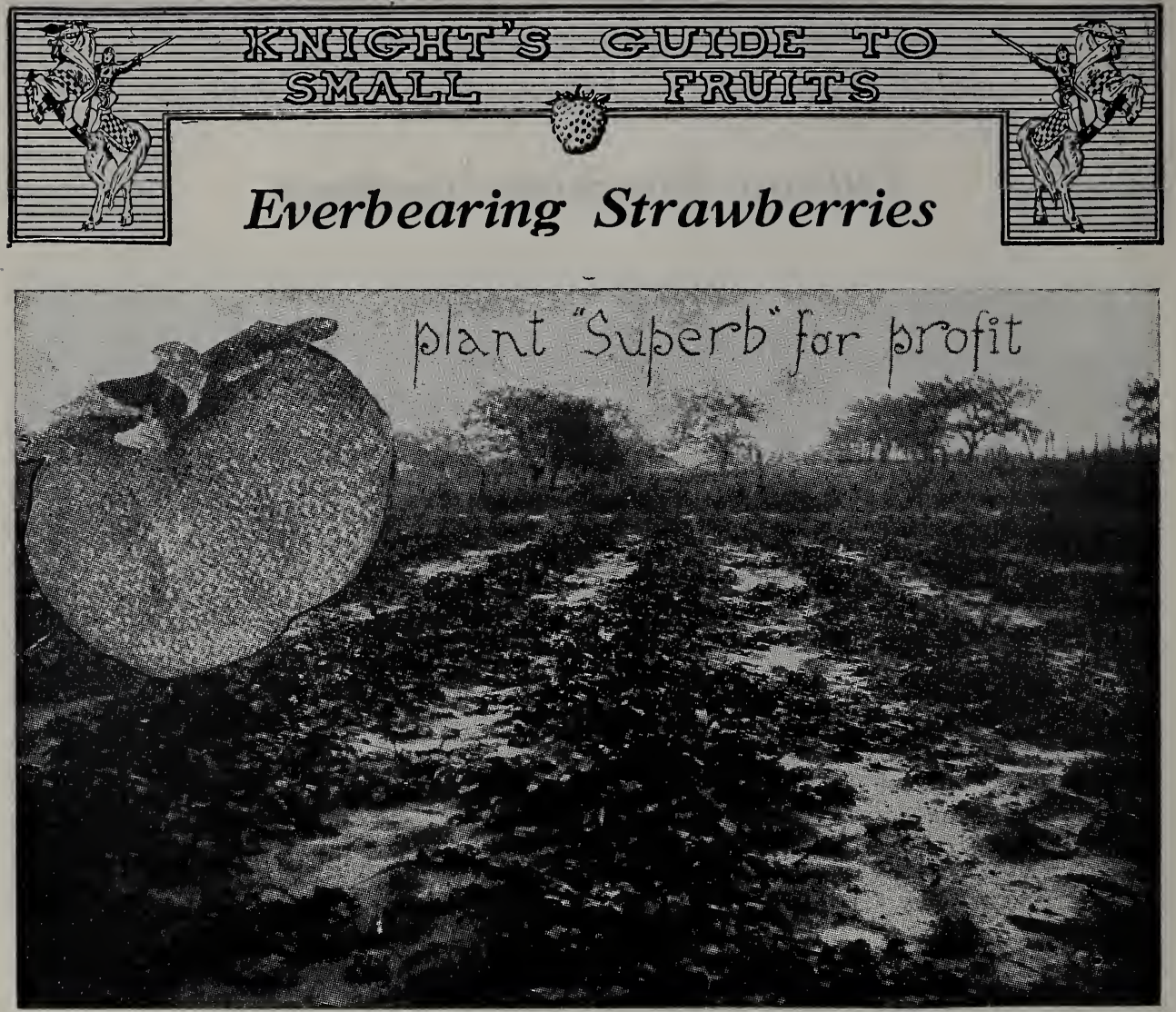

Everbearing Strawberries are one of the most valuable additions to fruit growing that has ever been known. There is absolutely no doubt as to their value and although thousands and thousands of everbearing plants are being set every spring, it will be a good many years before the price of fresh strawberries in the fall is lower than at the present time for the demand is enormous and people are willing to pay fancy prices for strawberries in what they consider, out of season. So if you have never grown everbearing strawberries, get a start of them this year for they are indispensable to the home garden and they open up an entirely new and profitable field to the commercial grower. But by all means place your order for plants early, for there has never been a season when we have had enough plants to supply all orders, even with a full crop.

\section{Superb Per.}

On our grounds Superb is still the leader of all fall varieties. Not as to quantity of fruit produced, but as to size, handsome appearance, and quality. The berries grow very regular in shape and ripen all over at once. They are very large and attractive, having a dark red glossy color that is very attractive. In our opinion there has never been a variety introduced, either spring or fall bearing, that has so much vitality and such fruit producing qualities as Superb. It seems almost unbelievable that, after producing a crop of fruit the first fall after being planted, they will also produce as large a crop the following spring. as any of the spring sorts; still this is absolutely the fact and, besides, they will produce another crop the following fall. The plants are strong, healthy growers and make runners freely; however the most fruit can be had by planting for hill culture and keeping runners removed. We have a large acreage of Superb this year but, as stated above, they set only a few plants and as the demand is so very heavy we will be sold out early.

Dear Sirs :-

Michigan, May 12, 1920.

I sent for about a dozen catalogs last winter and received them and placed a trial order with each one. Now take it all in all, I have received the best treatment, the best goods and the best packing from you than from any of the others.

Yours respectfully,

ELMER · H. NEVINS. 


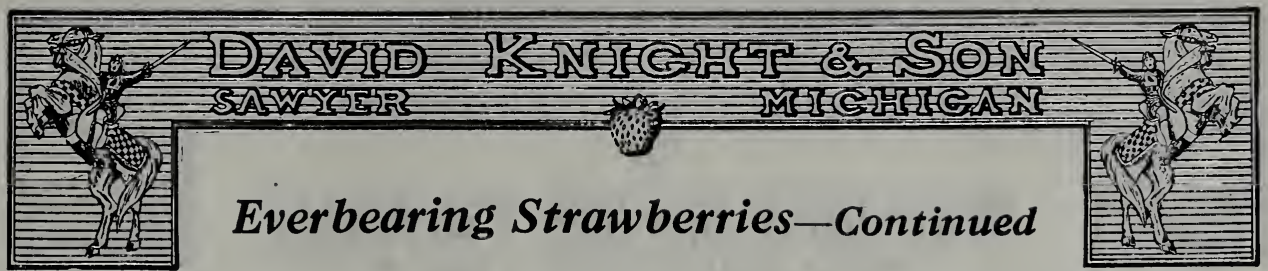

\section{Progressive Per.}

A good many growers rate Progressive as the best of the everbearers and Superb second. This has not been our experience, although Progressive is certainly an exceptionally worthy sort and a close second to Superb. The berries are of fair size, rich deep crimson in color, nearly round and very glossy. The plants are strong growers having an abundance of large healthy leaves. This variety, like Superb, will produce a bumper crop the second spring planted after bearing a good crop the fall before. There is no doubt but what Progressive is the most prolific bearer of any of the everbearing varieties, and the quality of fruit is unsurpassed. We have a large acreage of both Progressive and Superb this year and the most of our patches, as you will notice from photographs on this and the opposite page, made a very good growth; however, the demand is so heavy that we will surely be sold out early. Your only safeguard, then, is to get your order placed just as soon as this catalog reaches you.

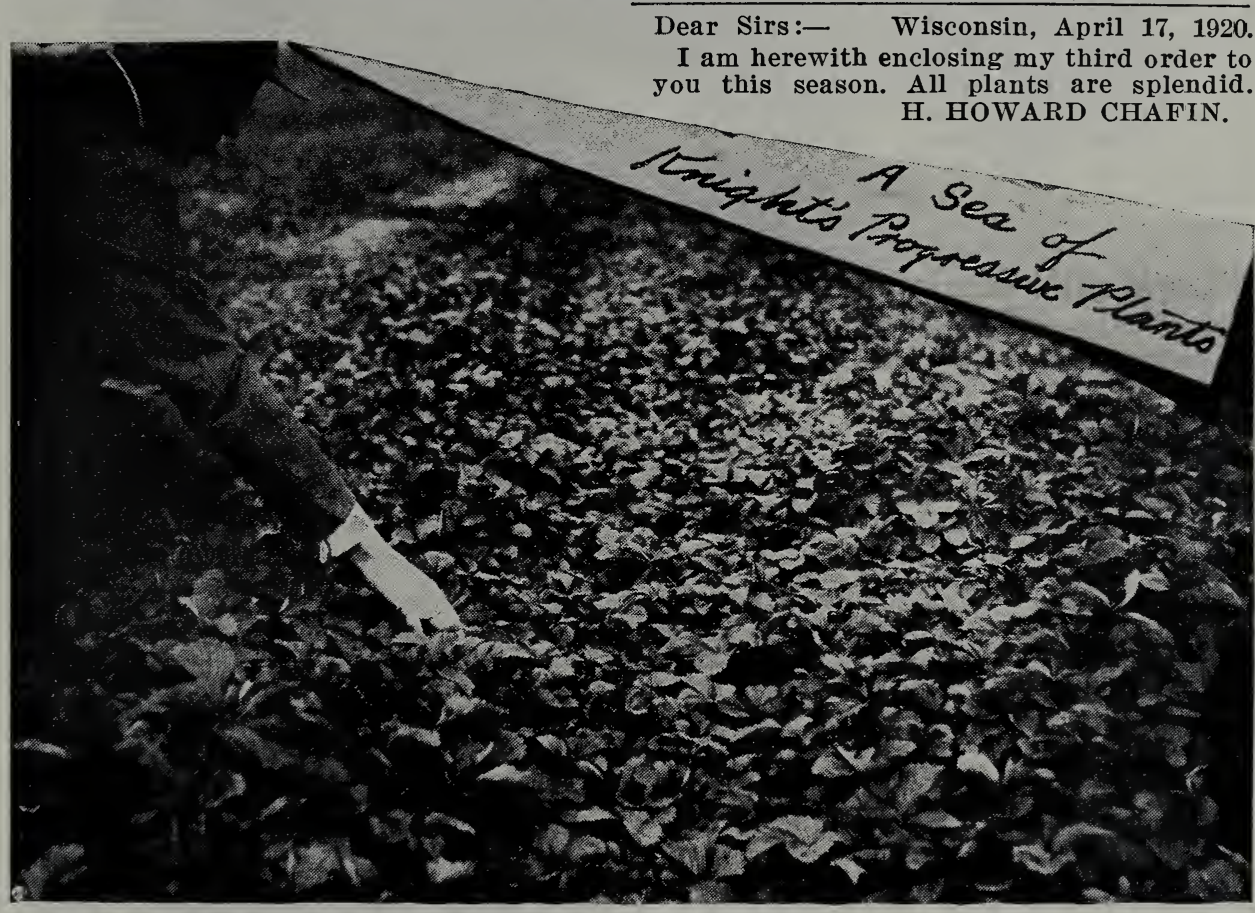

Notice the strong healthy plant growth in this patch of Progressives. Ordering plants from beds like this one is your assurance of success.

Hundreds of growers could not get plants last year because they ordered too late. Hundreds will do the same this year. But don't you be one of them. Order from

\section{Knight-Today}

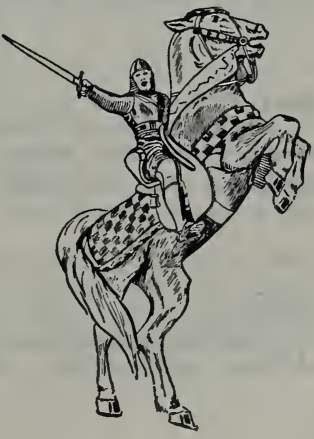




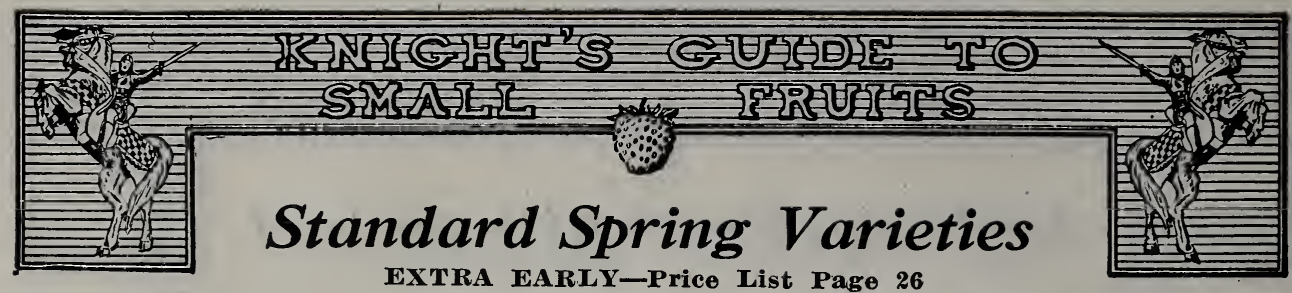

\section{Charles I.}

Per. This has proven one of the best and most profitable of any of the extra-early varieties grown in this section of the country. It commences bearing earlier than the old Michael's Early and is much superior to that variety in productiveness, flrmness, and quality. The berries are of good size, good color, and good quality, and ripen at a time when they can be sold at a good price. If you are in need of a profitable extra-early variety, be sure to include Charles $I$ in your order.

\section{Campbell's Early}

Per. Campbell's Early is described as being the "greatest of all strawberries," earlier than Michael's Early, but having a size, color and quality equal to the best of the mid-season or late varieties. In fact, it is said to be as large as

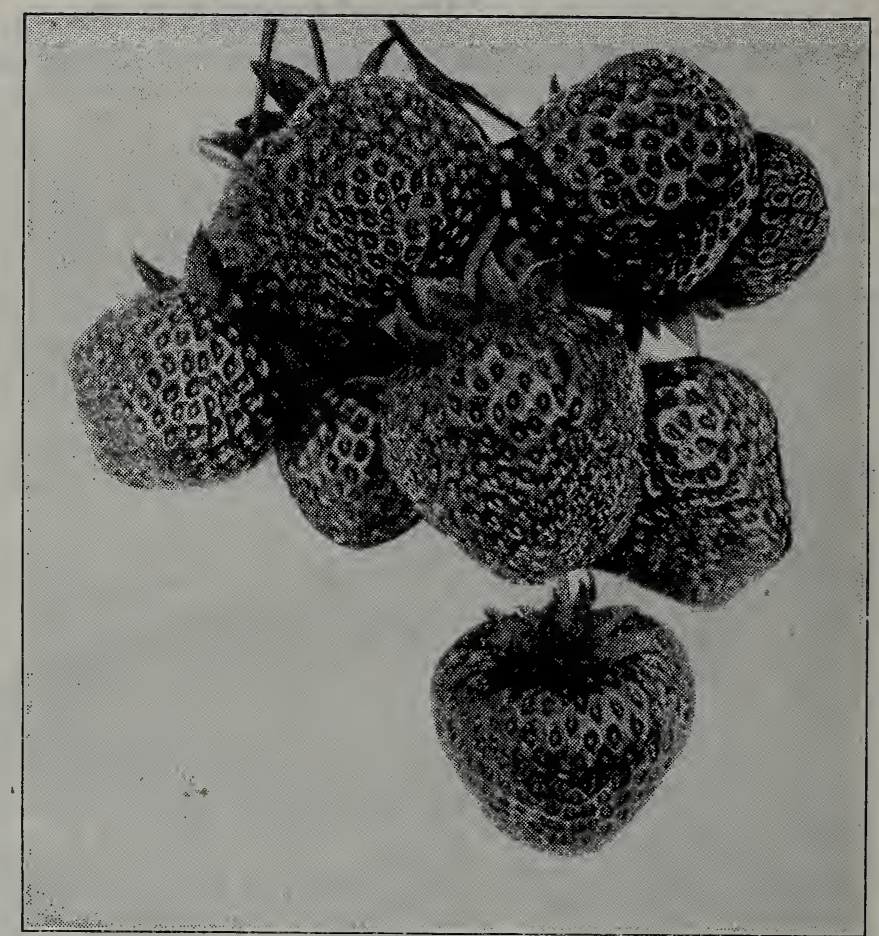

Charles First.

Gandy but with the added advantage of being more productive and the berries ripen all over with no green tips and are never knotty or ill-shaped. It is not an excessive plant maker but forms a good fruiting row and the plants are large and healthy with a light green upright foliage which amply protects the enormous crop of large, beautiful rich red berries.

There are few really good extra early varieties, and for that reason you should give Campbell's Early a trial for it may prove just the variety you have been looking for.

We have only a limited supply of plants this season so would advise placing your order early.

Gentlemen :-

Walla Walla, Washington, April 17, 1920.

The plants arrived all right April 13th. They were in good shape and have healed them in waiting for favorable weather to set them out. J. J. MORRISON.

Dear Sirs:-

Doniphan, Kansas, April 19, 1920.

Our basket of 500 strawberry plants, 20 bunches of 25 to the bunch (or rather an average of about 27 to the bunch) arrived safely today. They were in No. 1 shape and everyone was surprised to see such fine plants in such good condition from so far.

FREDERIC BOLSOM.

Gents :-

Conneaut, Ohio, April 20, 1920.

Beg to advise you that the strawberry plants you shipped me last Saturday arrived Monday in excellent condition. Am very much pleased with them. W. HEE. 

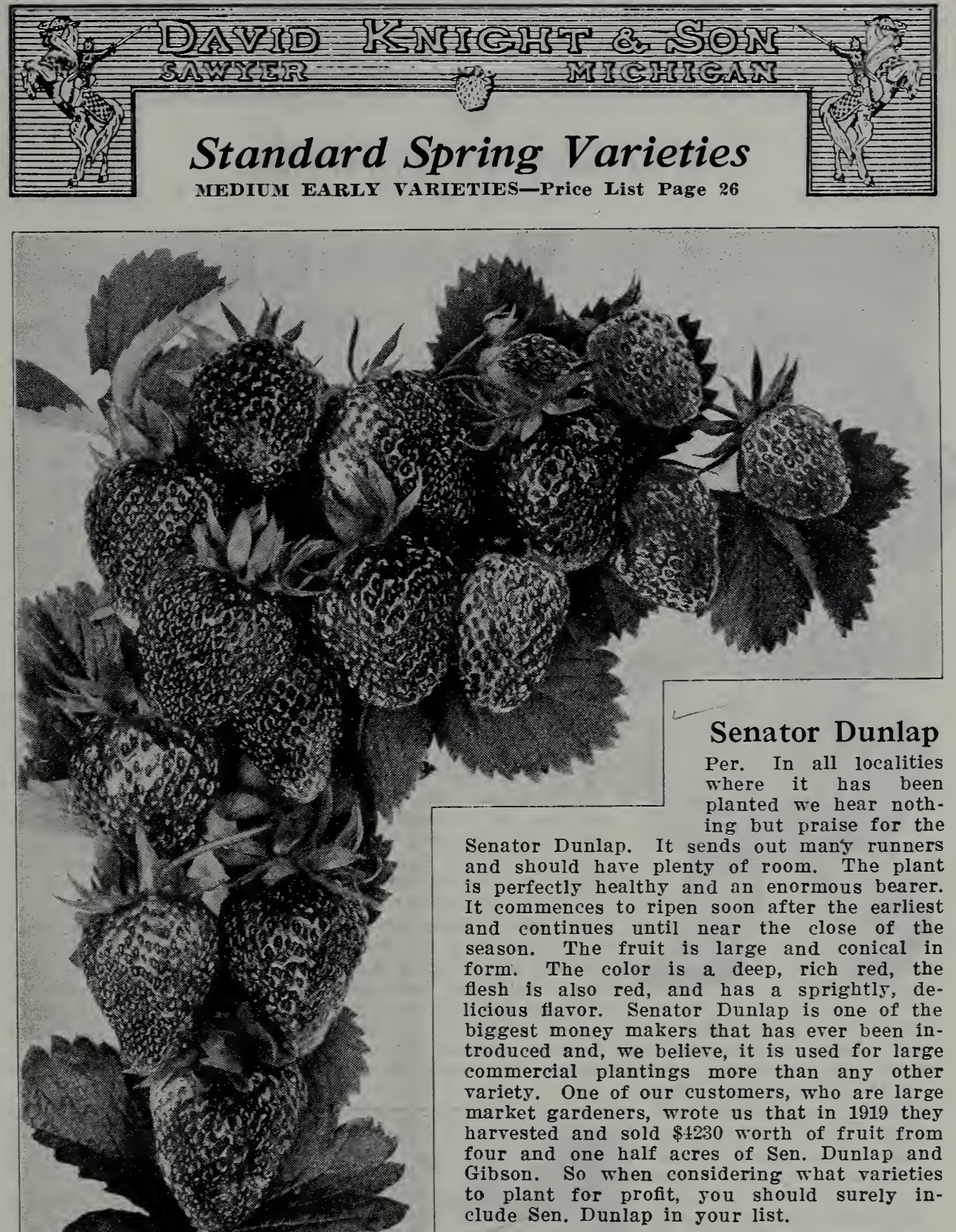
clude sen.

Haverland Imp. Exceedingly producOne of the most popular of the well-tested varieties. It will stand more frost than most anj other variety, often bearing large crops when others are killed. We can always depend on a large crop. Few varieties will produce more fruit per acre or sell for more money. Demand for plants is always great.

Warfield Imp. The Warfield is a great plant-maker, covering the soil, with only in market, when well grown. It is redies are deep glossy red and are very attractive by canners. Produces immense crops of berries, but must hare a rich, moist soil, good culture, and the plants must be kept thinned. 

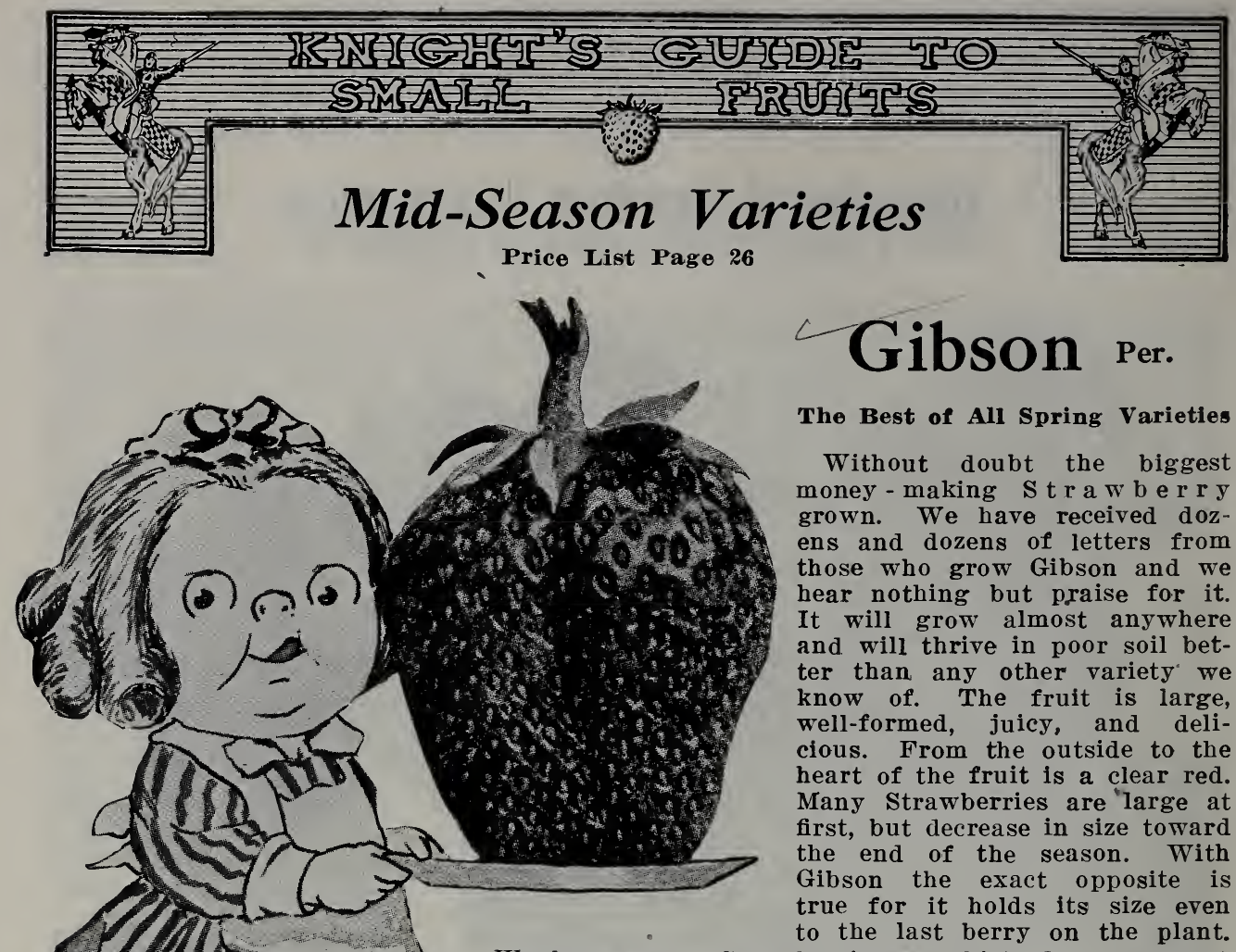

Gibson Per.

The Best of All Spring Varieties

Without doubt the biggest money - making $s$ t $r a w$ b e r y grown. We have received dozens and dozens of letters from those who grow Gibson and we hear nothing but praise for it. It will grow almost anywhere and will thrive in poor soil better than any other variety we know of. The fruit is large, well-formed, juicy, and delicious. From the outside to the heart of the fruit is a clear red. Many Strawberries are "large at first, but decrease in size toward the end of the season. With Gibson the exact opposite is true for it holds its size even to the last berry on the plant. We have grown Strawberries for thirty-five years and we believe Gibson to be the best variety we ever had.

For market you can't beat Gibson for it ships well, arriving at distant markets in prime condition. The handsome appearance of the fruit and its delicious taste cause it to pull the highest prices in any market. The plant is a strong grower and produces big crops. It is as near rustproof as a plant can be.

Mr. E. C. Nord, of Rice Lake, Wisconsin, in sending in a picture of his crop of Gibson, says: "The patch I planted with Gibson that I bought from you is the best that I ever had. Last year they yielded me a net profit of $\$ 665$ per acre and in a dry season at that. I had several Strawberry-growers inspect my patch and they pronounced it the finest they had ever seen. By looking at the accompanying picture you will note that my patch is located on the lake shore, and the first season I harvested the crop most of the berries were hurt by the late frosts. My Gibsons were not affected at all."

While we have a larger acreage of Gibson than ever before, the National popularity of this grand variety makes a demand far in excess of the supply, so take our advice and order early and heavily of Gibson, for it will surely pay you big money.

Purcellville, Va., 5-3-20. Dear Sirs :-

Many thanks for the nice lot of strawberry plants which were received in good condition.

MRS. J. A. LYNN.

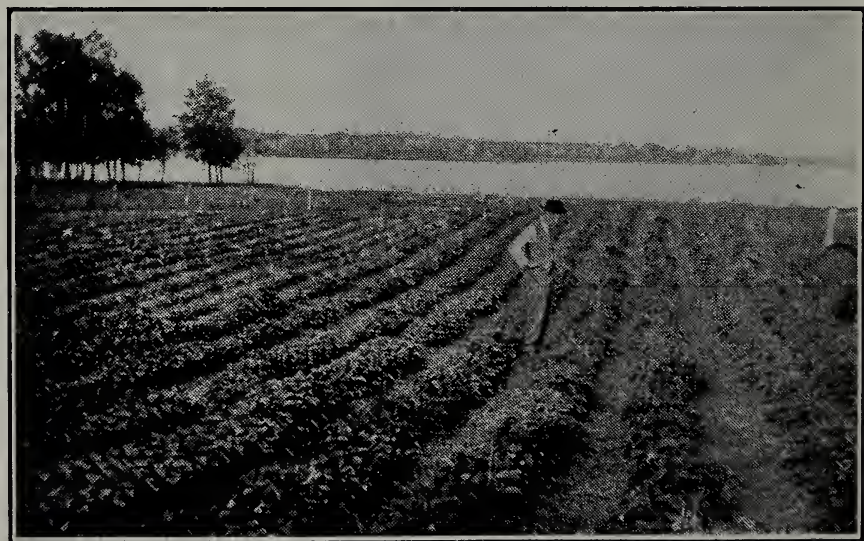

This is Mr. Nord's patch of Gibson. His net profits were $\$ 665$ per acre. How would you like to pull down money like that? 

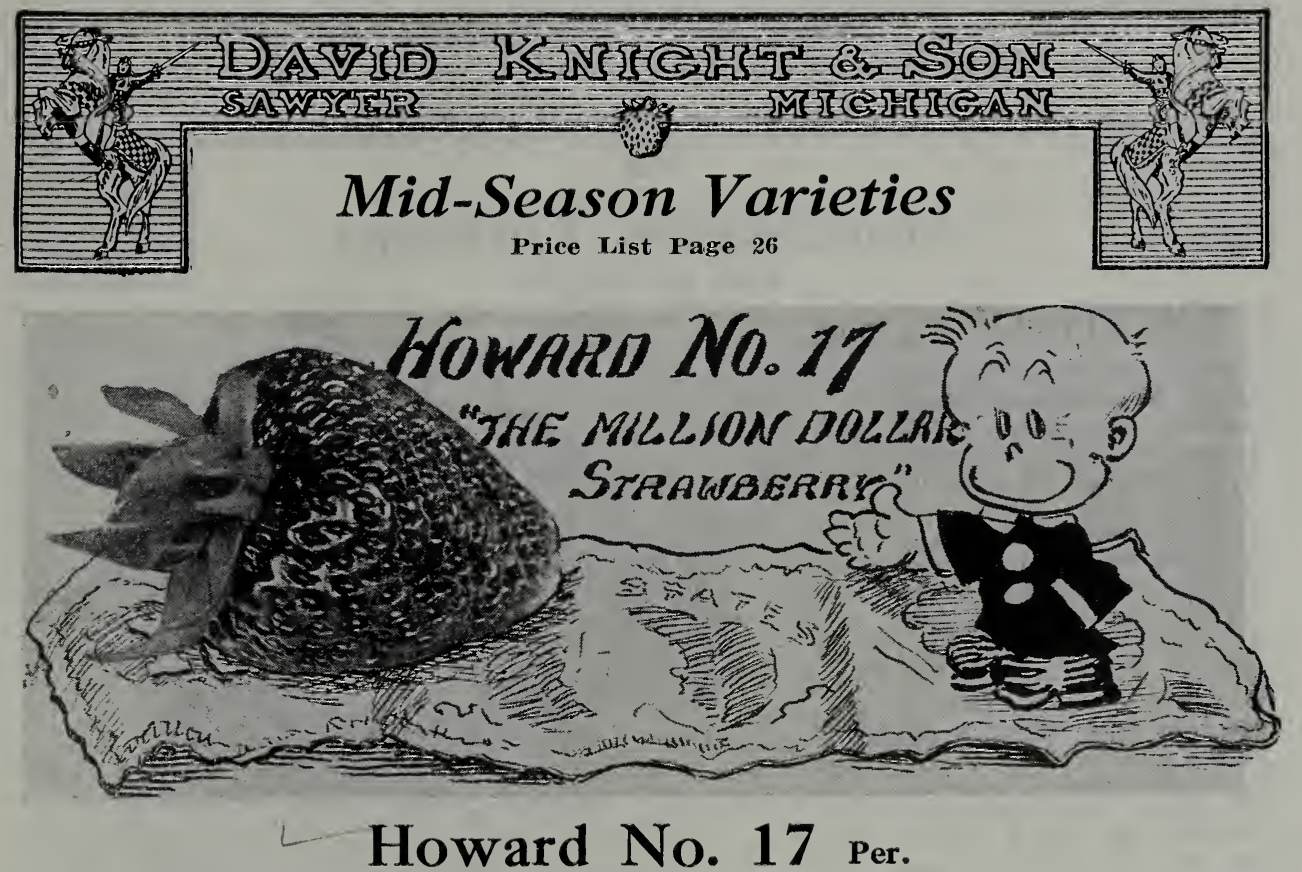

If you have been looking for a large, handsome highly flavored berry; one that produces immense crops that demand the very highest price in market; then your search is ended. Howard No. 17 is the answer. And let use tell you why: Howard No. 17 is one of the largest berries grown. It is never misshapen and maintains its size and regularity during a long fruiting season. In color it is a beautiful, rich glossy red and of a quality that could not be improved upon. It ripens early and produces the bulk of its crop before the market is glutted with other varieties. It is a splendid shipper, arriving at distant markets in excellent condition. The Howard No. 17 plants are wonderfully vigorous and healthy, in fact they seem to be immune from disease, and after producing an immense crop of fruit, the foliage appears just as green, healthy and luxuriant as at the beginning of the season.

Howard No. 17 was first introduced by Mr. C. E. Chapman of Conn., in 1918. But for about 15 years previous to that time it had been grown by a little coterie of farmers in Massachusetts who refused to sell any plans from it. However, in time a few of the plants were obtained by the Connecticut Agricultural College and from them Mr. Chapman received his stock in 1916. A part of the Conn. Agricultural College report for 1918 was as follows: "Howard No: 17 is the best variety we have tested at the college in ten years." And Prof. A. T. Stevens says of it: "I have grown Howard No. 17 for thirteen years and have yet to find it's equal.

Howard No. 17 has now been grown in 20 states and every report received has been glowing with praise, so we do not hesitate to advise all of our customers to buy some plants of this grand new variety. The price is a little high, as compared with other varieties, but if you had to pay $25 \mathrm{c}$ a piece for them you would get value received. Our plants were obtained direct from the introducer in 1919 , and, as our original purchase was small, we haven't a large supply this season, so it is absolutely necessary to place your order early as our supply will not nearly meet the demand.

Glen Mary Per. A strong, vigorous-growing, healthy plant. Some seasons it Glen Mary has pollen to fertilize itself, but it is better to plant it next some perfect-blooming variety, like Dunlap, Brandywine, or Gibson. The Glen Mary is fast growing in favor all over the country. The berry is so large and fine looking it always commands the highest price in market. It needs good soil, good culture, and plenty of room in the row.

Pocomoke Per. From the standpoint of a commercial grower this comes very near being a perfect variety. It is a healthy, luxuriant grower, making plenty of runners, and is an abundant bearer of large, firm, bright red berries. Never misshapen and holds up in size better than a great many varieties. It is a superior berry in every way, with exception of being a little tart; however, this makes it very popular as a canning berry. Needs no petting and will produce large crops under reasonably good culture.

Bubach No. 5 Imp. One of the largest berries of the old varieties. It is popular in nearly all sections of the country. The plants are model growers, making just enough plants for nice fruiting row. They do not make plants very freely and for that reason they cannot be sold as cheaply as some other varieties. We have a good stock, but as the demand for them is always heavy, you should order early so as to be assured of getting them. 


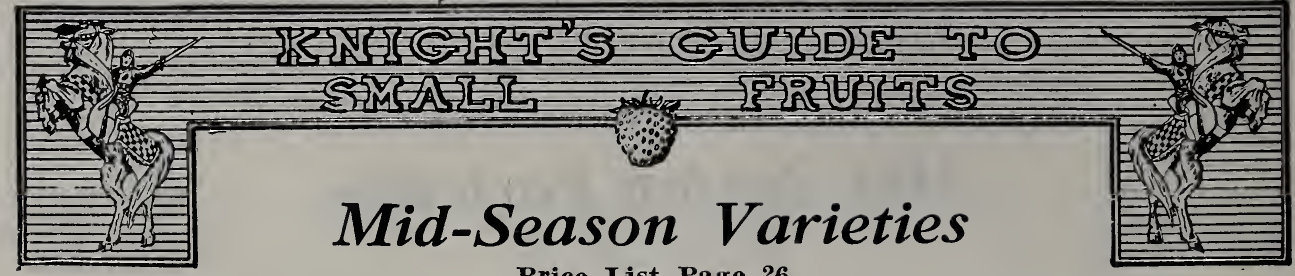

\section{HERITAGE}

Per. The plant is very large, of extremely heavy texture, some single-crown plants carrying foliage with a spread of 20 or 22 inches. Deep rooted and extremely free in fruiting, beginning to ripen its fruit about early midseason and continuing to very late. The berry is dark, shiny, crimson to the center. Has a perfect blossom. Carries an unusually heavy green caly $x$, adding decidedly to its market value. Extremely large from the flrst picking to much above the average for the main crop and continuing large after the better known varieties are gone. We have fruited the Heritage for several seasons and every year grow more enthusiastic over it. Don't fail to include this one in your list, as it will prove a moneymaker for you.

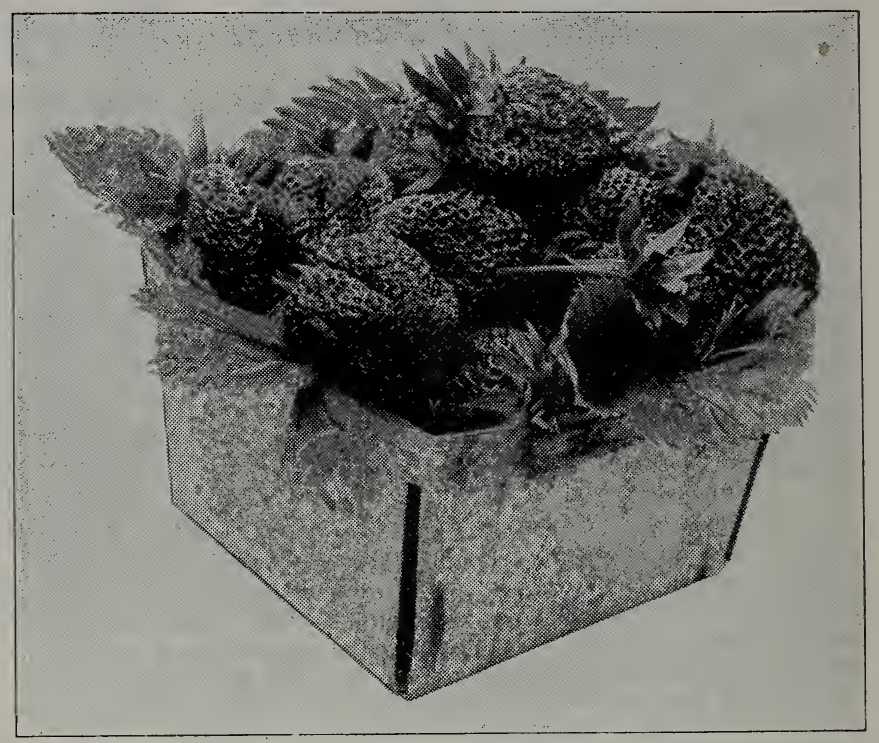

Heritage.

Wm. Belt Per. The plant is very large, a most luxuriant grower and remarkably productive. It is medium in ripening, neither very early nor very late; size is very large indeed. In form it is conical, rather long and quite uniform in shape. The color is a brilliant, glossy red-as near perfection as was ever seen in a berry. It ripens all over without green tips. The quality is good-better than is usually found in large berries. The foliage of $\mathrm{Wm}$. Belt, as grown here, is affected with some rust and to insure a good crop every year, it should be sprayed, and it should be planted on welldrained, warm soil.

Uncle Jim Per. A good grower of large, stocky plants, well spaced for fruiting. The fruit is large, highly colored, quite firm, and of good quality. A choice among the standards. The plant is very large, and the roots go deeper than any variety we have, which makes it well able to resist drought.

Minnesota No. 3 Per. This variety was originated at the State Fruit Breed3 ing Farm at Excelsior, Minn., about six years ago. That Experimental Station is recognized as one of the best in the country, having originated many valuable hardy varieties of fruits. And the fact that this variety stands at the head of about fifty sorts tested there speaks well for it. Minnesota No. 3 is a cross between Sen. Dunlap and Pocomoke. In comparison with Sen. Dunlap it has the same season of ripening and the same beautiful dark red color and delicious flavor, but the fruit is much larger and the season of fruiting much longer. It is wonderfully productive of beautiful bright red berries which are very firm, making excellent shippers to distant markets. It is a splendid plant producer and the plants root deep so as to offer a great resistance to drought. Also it is wonderfully hardy, coming through the hardest winters in good condition where more tender varieties succumb. Don't fail to get a start of Minnesota No. 3 this year, but order early as our supply of plants is limited.

Dear Sirs:-

Ford City, Pa., April 23, 1920.

$I$ received the plants $O$. $K$. They are in good condition. Thank you very much. You can expect another order not later than next spring if all is favorable. 


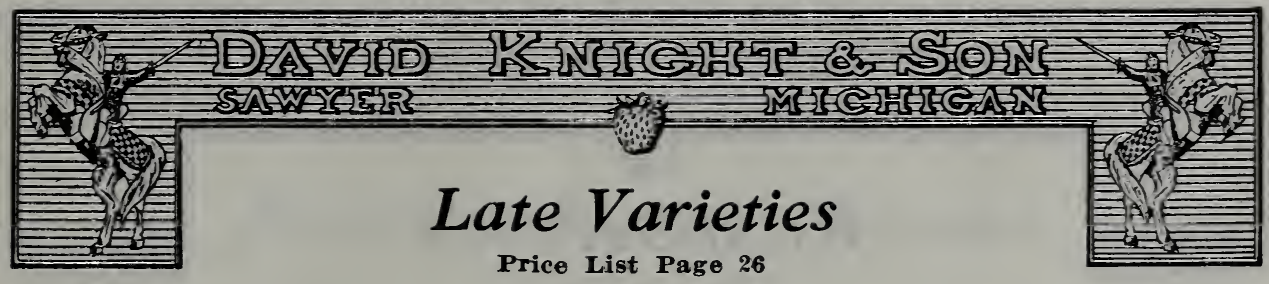

Aroma Per. One of the old standard varieties that, in certain sections, continues to be a favorite in spite of the many new varieties being introduced. It seems to be better adapted to the South and Southwest, although it has been grown very successfully here in Michigan. Fruit is very large, bright red in color to the center, and has a delicious flavor. It is productive and firm of texture, making it a great shipping berry. It has a long fruiting season and continues good until the end. The demand for this variety is usually far in excess of the supply.

Brandywine Per. A vigorous, perfect-blooming plant; tall fruit-stalks; broad, heavy, dark green foliage. Plants productive, having four and fire only a little more dull; large yellow seeds on surface. Flesh red clear through, firm, somewhat acid, but with sprightly flavor; ripens medium to quite late. Does best on heary loam or heavy clay. Like all large berries, they should have plenty of room in the row, so they can build up strong stools.

G A N Y Per. This is one of the most reliable, large late berries that is grown. It is one of the old standard varieties that you can depend upon. It is a strong grower and a good plant-maker. The large, handsome appearance of the fruit always commands for it a high price in market. The fruit always grows large and is one of the best shipping varieties known.

Sample Imp. A valuable, large, late variety. Sample has scored such a marked success in many places that no progressive grower can afford not to plant some of it. The successful man is he who tests all really promising varieties and in that way quickly finds those suited to his own soil, climate, etc.

STEVEN'S LATE CHAMPION Per. This is one of the best and most strong vigorous plants which produce an abundance of fruit. The plants send out a great many runners that take root quickly and cover the ground if not restrained. The fruit and blossoms are well protected by the abundance of foliage. The fruit is large, long, and slightly flattened. The color is a deep red, the flesh being also red. It ripens all over and is very firm, being one of the best varieties to hold up after picking that we know. Its season of ripening is about with that of the Gandy and is a worthy rival of that grand old variety as a popular and profitable late berry.

\section{Teddy Roosevelt Per.}

\section{A Wonderful Variety of Real Merit}

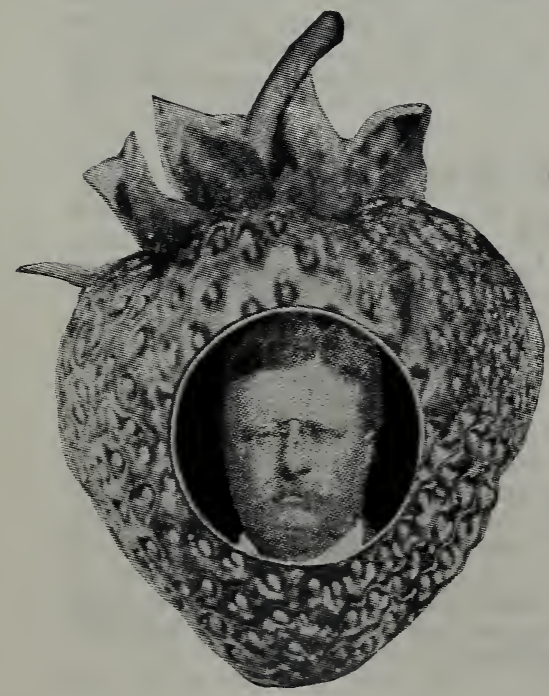

This variety is forcing itself into popularity by the force of its remarkably good qualities. Several years ago a few of these plants came into our hands and after watching them produce superior crops of fruit year after year, we have become so enthusiastic over them that we want every one of our customers to plant some Teddy Rooserelt. Remember, please, we introduced the wonderful Gibson several years ago and predicted that it would become the most popular berry grown. That very thing has happened. Now we predict for Teddy Roosevelt an equal suceess, and the people who get a start of this grand variety at once are the ones who will profit the most from it. In season of ripening, the Teddy Rooserelt is late. The fruit is large, brilliant red, of excellent flavor and so firm that it always reaches market in good condition. The plants are unusually strong and healthy and can be depended upon for a crop when adverse weather conditions seriously affect other varieties. You will make no mistake by planting Teddy Roosevelt so get your order placed now, while we still have the stock with which to supply you. 

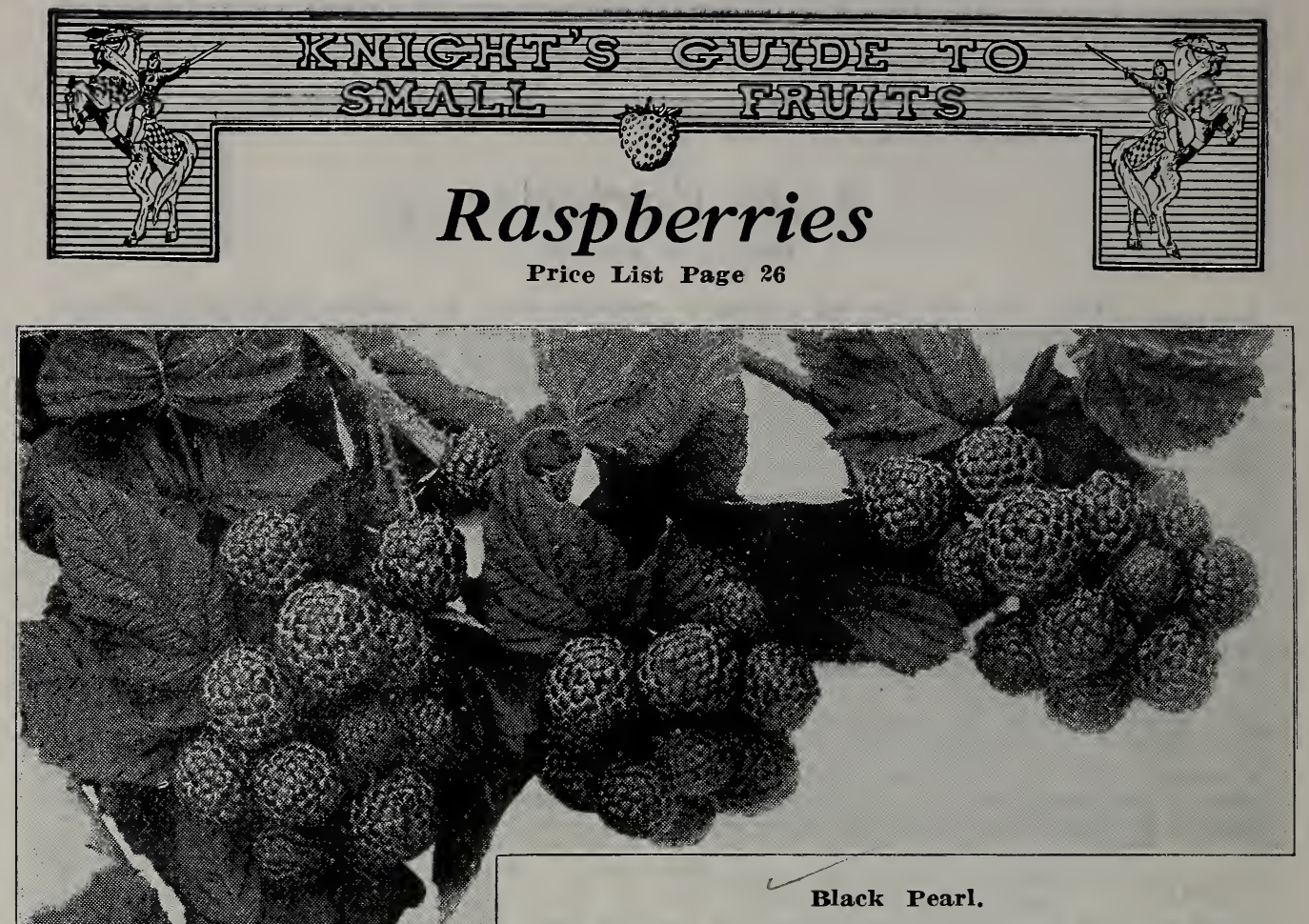

Either red or black Raspberries are a profitable crop wherever grown, and after being planted are not hard to care for. As with strawberries the same land that will produce good corn or potatoes will also grow good Raspberries and with just about the same amount of cultivating and hoeing that you would give corn and potatoes. Black Raspberries should be set from 3 to $3 \frac{1}{2}$ feet in the row and the rows 7 feet apart. As soon as growth starts and plants are from 18 to 20 inches high, pinch out the top of each cane, which causes them to send out laterals and gives a larger fruiting surface for the following year. Red Raspberries should be set 2 feet in the row, and the rows 6 to 8 feet apart. Do not pinch off the tips of these, but the rapid-growing kinds, such as Cuthbert, should be cut back somewhat in the spring. After the fruiting season of both reds and blacks, cut out the old wood, thus allowing the new stalks to make a good growth for the coming season.

\section{Black Raspberries}

BLACK PEARL This variety originated near St. Joseph, Missouri, a few years ago and the fruit-growers in that section and the Middle. West generally have found it so profitable that they are planting more heavily of it than of all other varieties combined. One grower writes of it: "I have grown the Black Pearl Raspberry now for three years, and find it the best and earliest blackcap Raspberry grown in the Middle West. Earlier than Kansas and much more prolific than Cumberland." Another grower writes: "I have found them to be superior in many ways to the Cumberland and Kansas blackcap. They seem to be good drought-resisters and never winter-kill. The bushes will stand up under a big load of fruit and never tumble down like other varieties do. A great many plants are being sold for Black Pearl that are in no way related to that variety and all growers should be careful from whom they purchase their stock. There is absolutely no doubt as to the purity of the plants we offer for sale. If you want to grow Raspberries that will bring high market prices, or if you grow for your own table, you can't go wrong on Black Pearl. Destined to be come the greatest of all Black Raspberries. 

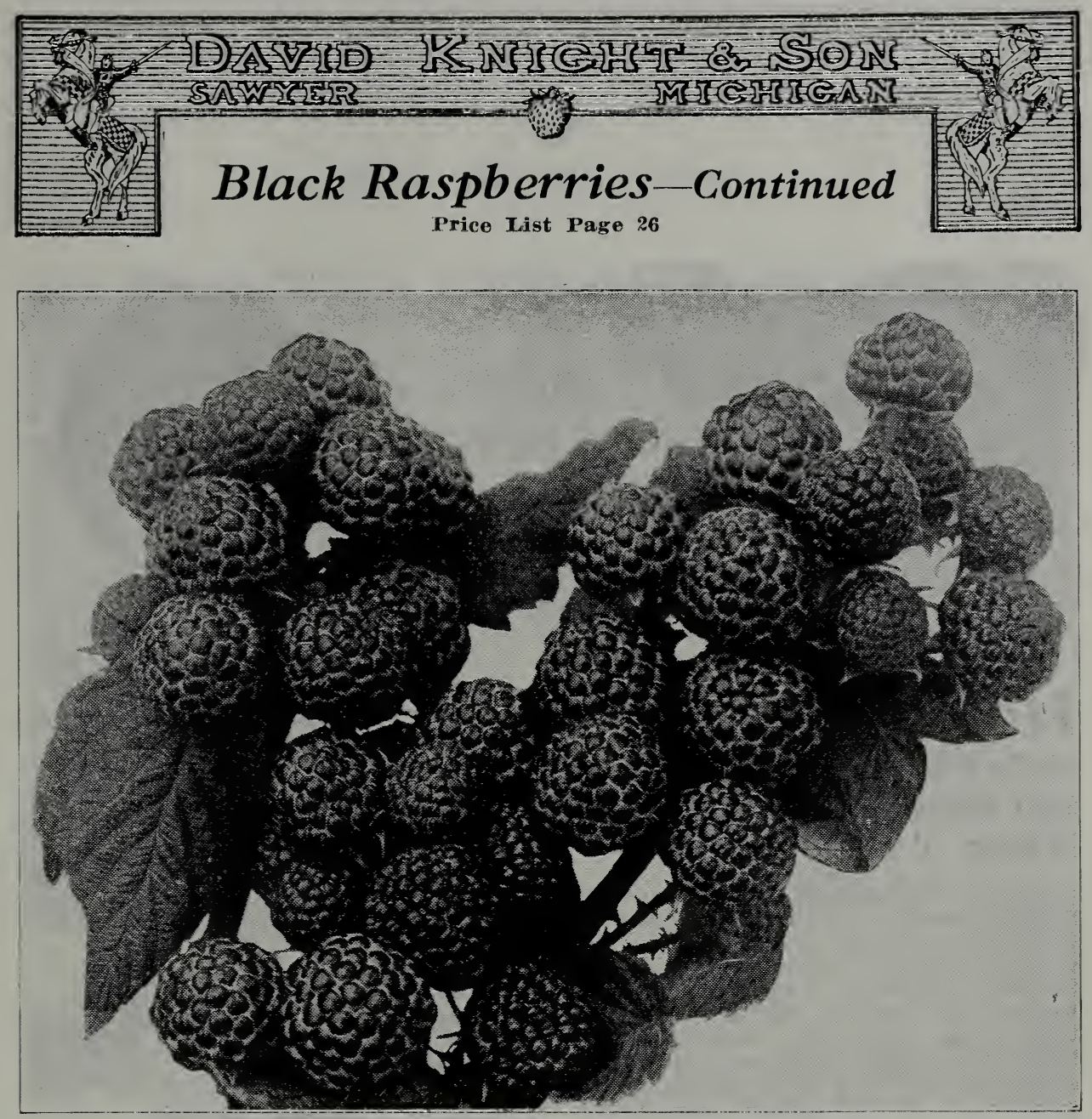

Cumberland.

Cumberland This is the largest of all the old standard blackcaps and one of was introduced several years ago, it has been forging steadily abead, until at present we believe there are more Cumberland grown than any other two varieties. There is only one reason for this and that is that they are money-makers. They are healthy, vigorous growers, throwing up stout, stock $\mathrm{y}$, well-branched canes that produce immense crops of magnificent berries. The fruit is large and firm, the quality is fine. Ripens in midseason and continues for two to three weeks. We have the finest crop of black Raspberry plants, particularly Cumberland, this year that we ever grew. If you want to be assured of a profitable patch, send to us for your supply of plants.

Plum Farmer Although this is one of the newer introductions in blackcaps, it Pas come rapidly to the front. In this section it is being planted very heavily for an early variety and our growers find it more profitable than any other sort. The berries are of large size and excellent quality. They are coal-black but corered with some bloom, which gives them a bluish gray appearance. The canes are strong growers, hardy, and produce a very large crop of fruit which is matured quickly. Don't hesitate to plạnt freely of Plum Farmer, as you will find it exceedingly profitable. Te have planted Plum Farmer quite extensively and find it all right in every respect. In fact it is an excellent variety for home use and market. If you want to sell your crop, Plum Farmer ripens before the markets have other varieties on sale. There is no question about its worth for it has proved it in many gardens.

I received the strawberry plants May 15th. They came thru in fine shape and as nice plants as I erer set out. W. J. FISK. 

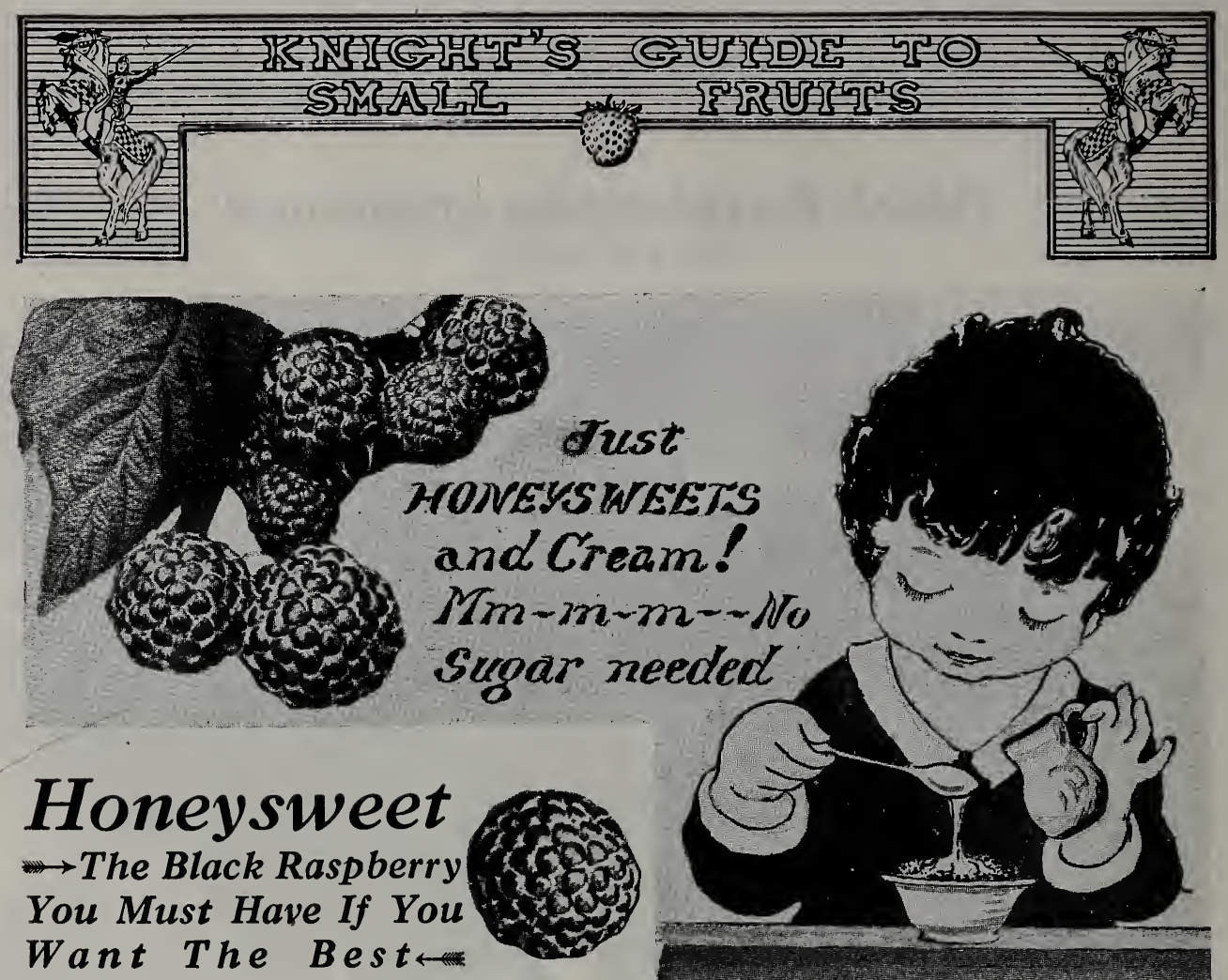

In 1919 we purchased our first HONEYSWEET plants. At that time we were a little skeptical of the claims made for this variety. But last summer we fruited itand were skeptical no longer. If you could have seen the immense crop of beautiful jet black fruit and could have tasted its HONEY SWEET flavor, you would have said with us "Here is the ultimate black raspberry." HONEYSWEET is a distinctive variety in every way.-In the vigorous growth of it's plants.-In the beautiful light green foliage.-In the large jet black fruit, without a sign of bloom.-In the firmness of the fruit, which does not crumble and will stand up longer after being picked than any other sort.-In the enormous crop produced.-And in its delightful flavor which is indeed distinctive and different from all other blackcaps.

You can depend upon the hardiness of HONEYSWEET.

You can depend upon the productiveness of HONEYSWEET.

You can depend upon the excellent quality of HONEYSWEET.

And you can depend upon the size and firmness of HONEYSWEET.

In fact HONEYSWEET has so much inherent firmness that, if pickers were scarce and if it were necessary to do so, the entire crop could be harvested in two or three pickings. Some other black raspberries have some of the good qualities of HONEYSWEET but we know of none of them that have all of its good qualities.

We have only a small number of HONEYSWEET plants and we are going to use half of that number for our own planting. So in order to give as many of our customers as possible a chance to get started with this grand new variety, we have limited the amount of each purchase to 25 plants. The price, $\$ 5$ for 25 plants, may seem a little high when compared with the price of other varieties but, after fruiting them, you will know that you have received full value for your expenditure. Don't delay in placing your order for, even with the 25 plant restriction, we will not have nearly enough to meet the demand.

Kansas One of the best and most widely known early varieties. In some sections it is planted more extensively than any other sort. The canes are strong and produce large crops of fruit. Berries are jet-black, of good size, firm, sweet, and of best quality. Kansas has been a general favorite for several years and we have sold thousands of plants from which we hear of excellent results. No matter whether you grow for your own table or for market, Kansas should be in your garden. Include some in your order. 


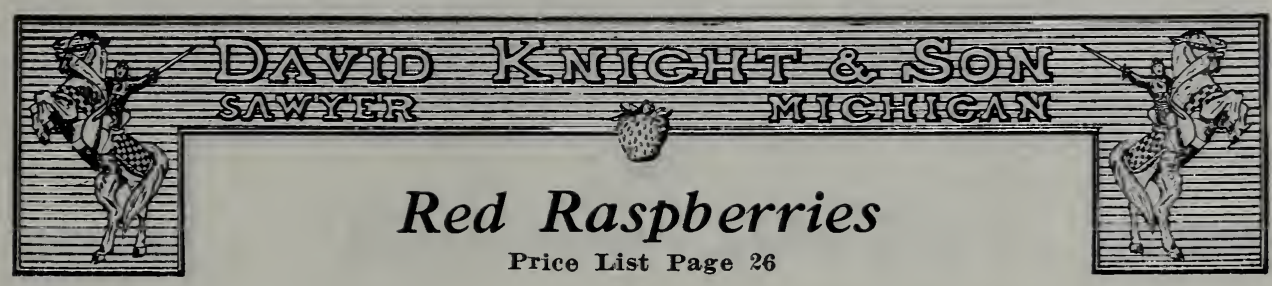

King Since its introduction several years ago, the King has been rapidly growing in public favor, until at the present time it takes the lead of all early varieties. Fruit is of good size and of a bright, beautiful color; it is firm and of exceptionally good quality. Immensely productive and commencing to ripen early, it alwass commands a good price in market. Making a selection from the old standards, our advice would be to plant king for early and Cuthbert for late, and you will always be assured of a profitable crop.

St. Regis This variety is unfact that it produces fruit from early summer until late fall. It is the earliest Raspberry to ripen, coming with the last of Strawberries. The spring crop is the main crop but they continue, in smaller quantities of course, all during the summer and autumn. By the last of August the new growth of wood, which has been maturing during the summer, is ready to bear fruit and continues to do so until stopped by frosts. The fruit is of good

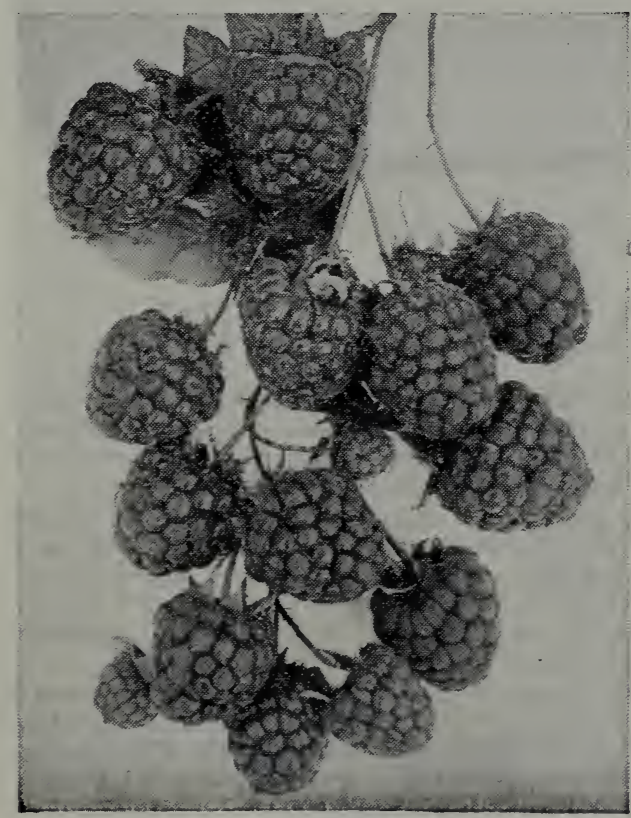

Cuthbert.

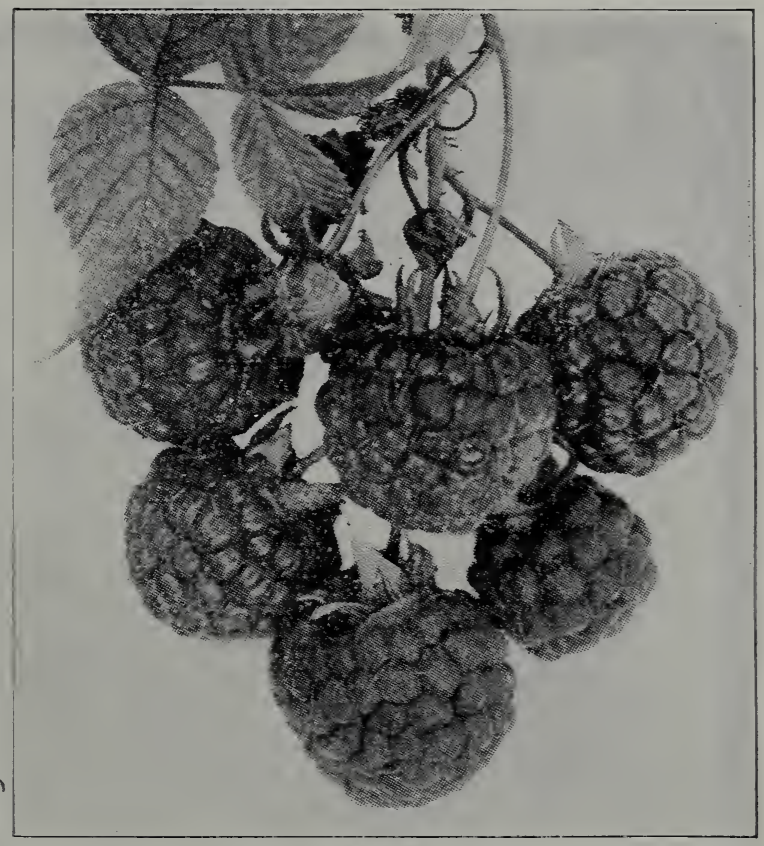

King. size, a beautiful, brilliant crimson color, of delicious flavor, and firm enough to ship to distant markets. In our opinion St. Regis will never be grown as extensively as Cuthbert and King for commercial purposes, but everyone should have some of them in order to enjoy delicious red Raspberries on their tables all during the season.

CUTHBERT This is one of the old standard varieties. It has been widely grown in all sections of the country and has giren excellent results both for home use and commercial purposes. Cuthbert is a good, rigorous grower and produces bountifully large and beautiful bright red berries. Probably no other red Raspberry is grown so extensively as the Cuthbert and the demand for plants is always heavy.

New Canaan, Conn., May 6, 1920.

\section{Gentlemen :-}

The plants you shipped April 24th arrived today in good condition in spite of the delay caused by strike conditions.

W. K. SMALLEY. 

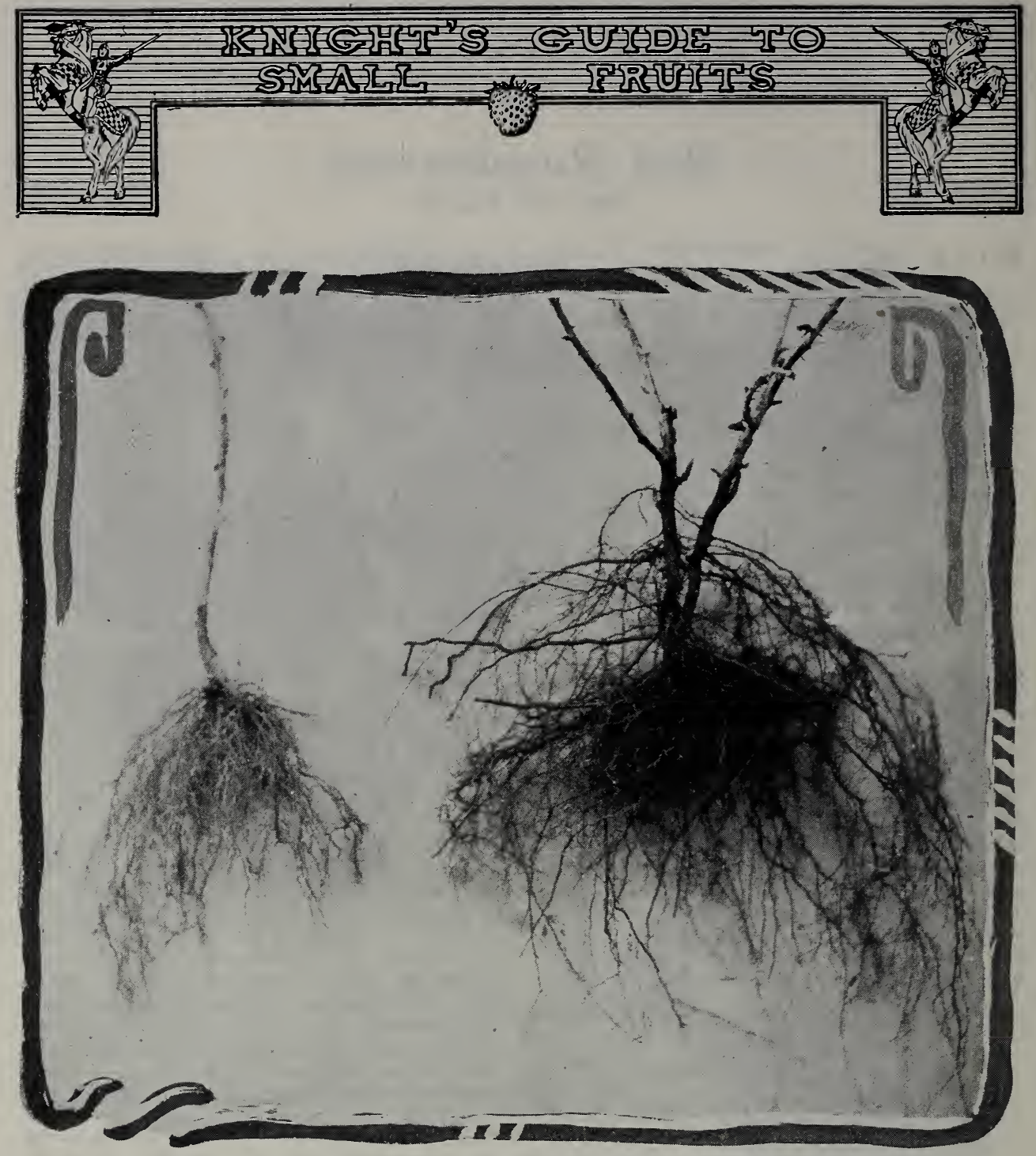

At the left a Tip Plant-At the right a Transplant. Note difference in size.

\section{BLACK RASPBERRY \\ TRANSPLANTS}

The illustration above tells you, more plainly than we can by words, just the difference between transplants and tip plants. The tip plant in the illustration is a strong vigorous one, but compare the difference in the two as to root system and top development, and you will know which will give you the quickest and largest returns.

For the first time we are offering transplants in our catalog. We have been growing them for several years past but always for the wholesale trade who, in turn, sell them thru their agents and at prices several times greater than we are listing them. So, in order that our customers may obtain these wonderfully strong well rooted plants at a reasonable price, we have grown a quantity of them and, if the demand justifies our doing so, we will continue to grow and catalog them every year.

Transplants are produced by setting out tip plants in the spring and carefully growing them for a season. The stock thus obtained, with its wonderful root and top development, will produce nearly a full crop of fruit the next spring after being planted, whereas tip plants do not reach their full production period until the second spring. So it can be readily seen that the additional price you pay for transplants over tips is decidedly justified. 

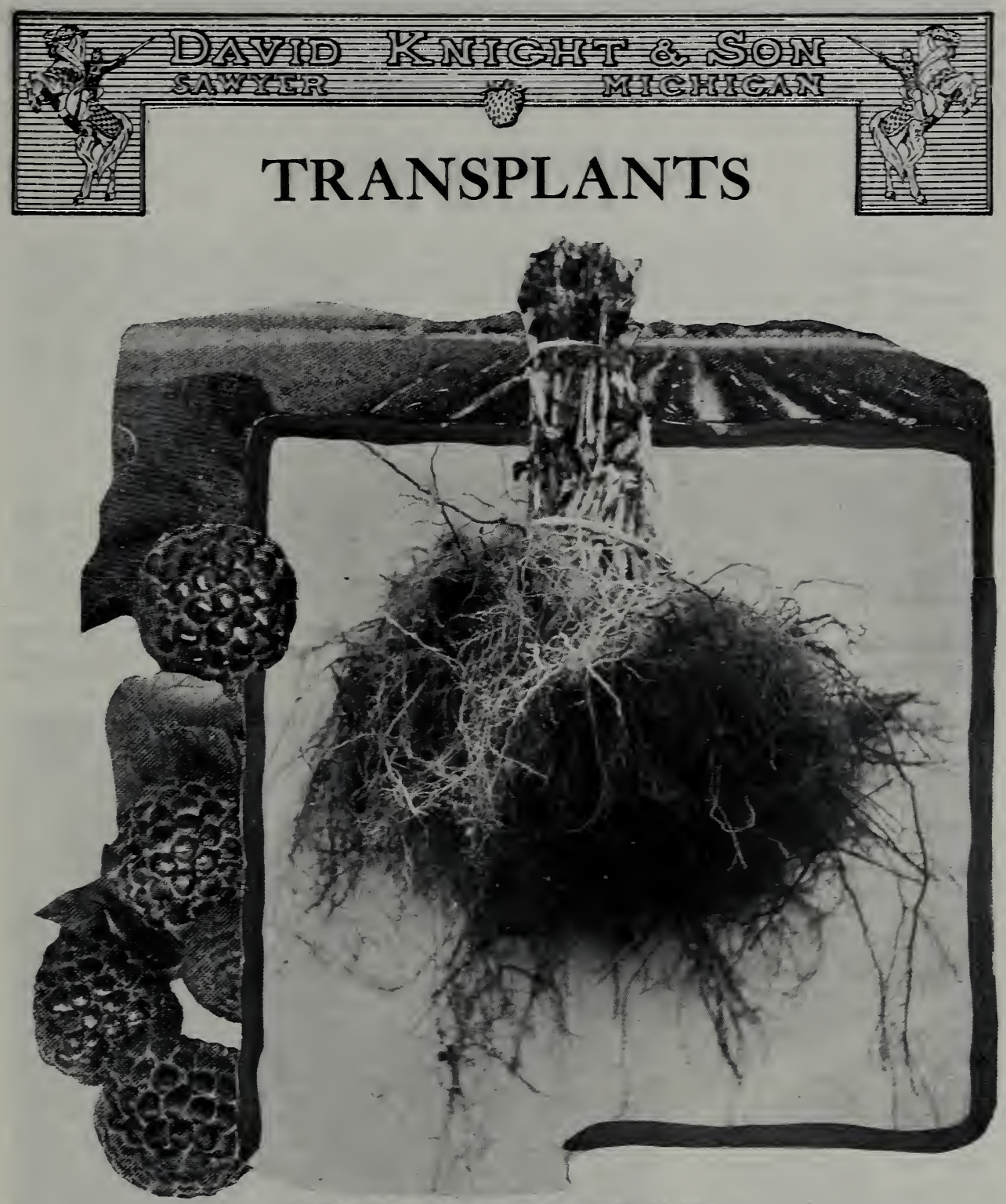

25 Wonderfully rooted TRANSPLANTS.

A short cut to quick results.

Below we are listing transplants of six of the best rarieties of black raspberries grown. You will find description of these rarieties in another part of the catalog.

Then ordering be sure to gire us second choice for fear our supply of the rariety you designate is exhausted when your order arrires.

On account of a limited supply and so that as many of our customers as possible can get some of these wonderful plants, we are limiting each purchase to 250 plants, with exception of Honersweet which has a limit of 12 plants.

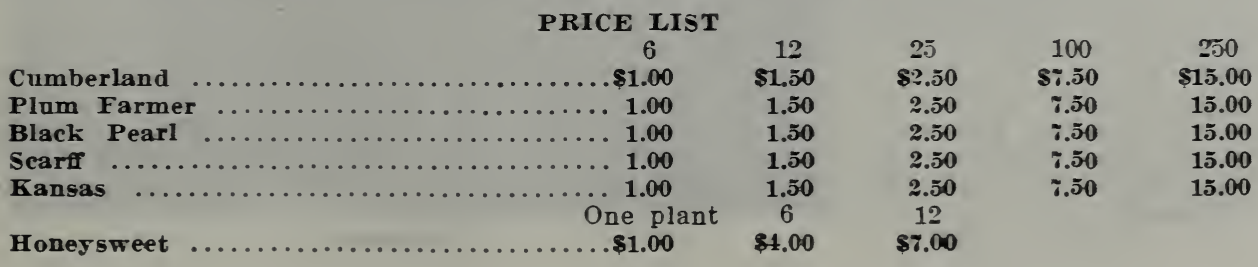




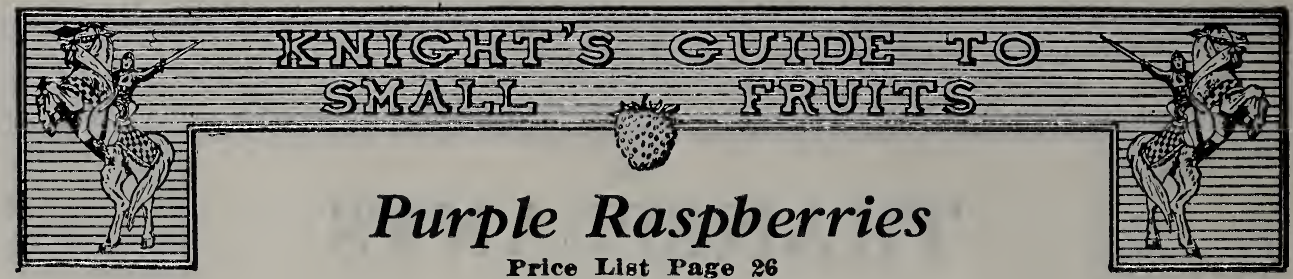

Columbian Purple Cap. This in our opinion, is the best of the purple varieties. It is very hardy and produces large quantities of berries of enormous aize, sometimes measuring one inch in diameter. The color is dark red, nearly purple. It shows its relationship to the black by propagating its plants from the tips. For a table berry and for canning purposes Columbian is unexcelled and every grower should have them for both home and commercial purposes. Our supply of plants will not last through the season so it will be necessary to place orders early.

\section{Blackberries}

In planting your Blackberry patch, select land that is full of humus and retains moisture well, for this crop ripens at a time when we can naturally expect dry weather, and if your patch is on land that quickly dries out, the crop will suffer. Culture for Blackberries is the same as raspberries, only they need more room and should be set 3 to 4 feet apart in the row and the rows from 7 to 8 feet apart.

Eldorado Has been cultivated many years, and under careful test at different experiment stations has never winter-killed or failed to produce a full finest fruit. The vines are very vigorous and hardy, enduring the winters of the far Northwest without injury, and their yield is enormous. Berries are very large, jetblack, borne in large clusters, and ripen well together; are very sweet, melting, pleasing to the taste, and have no hard core; quality unimpaired.

\section{Wilson's Early}

One of the largest and most productive of the early sorts. It is grown here largely for the market, as it pays better than any other variety. It always sells at a premium over other Blackberries in Chicago market and is daily quoted higher. The berry is large, jet-black, and holds its color, never turning red. It is not hardy, and here in the North needs winter protection to insure crop. By taking pains to lay it down, as is done here, it can be grown anywhere in the North. In the South it will need no protection.

Sparta, Wis., May 14, 1920. Dear Sirs :-

The plants arrived in good condition and were surely fine. Please accept my thanks for prompt shipment.

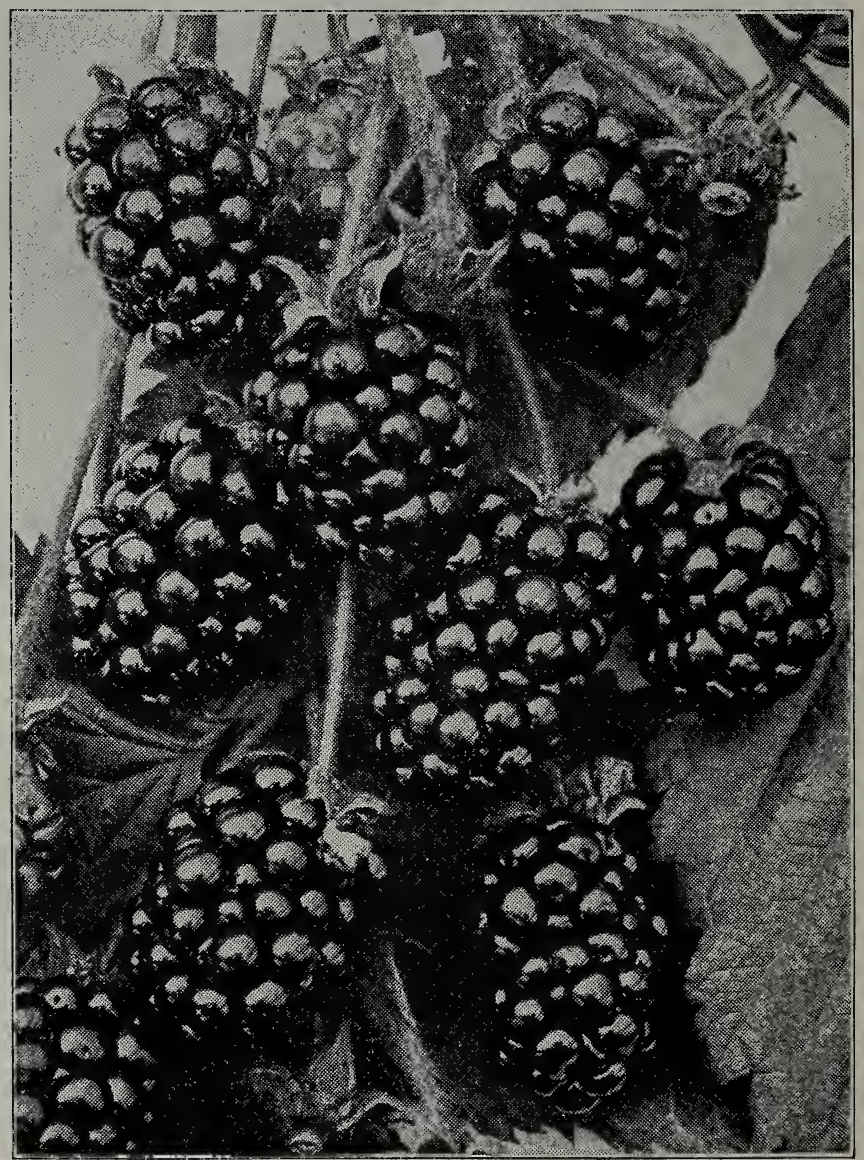

CHAS. GANTKE.

Eldorado. 


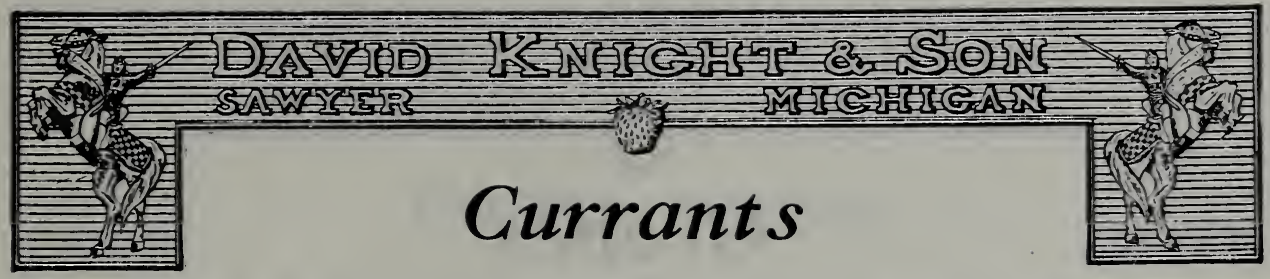

There should be at least a few Currant plants in every garden. The fruits make excellent jams and jellies, and the plants are hardy and easy to grow. Currants require a rich soil which retains moisture well. The plants should be set 3 to 4 feet apart and the rows 5 to 6 feet apart. Keep the patch well hoed, cultivated and trimmed.

Note.-On account of Federal Quarantine we cannot ship Currant and Gooseberry plents west of the Mississippi river.

PERFECTION A variety that has created a big sensation for several years past. It was propagated by scientific principles from the Fay's Prolific and the White Grape, and so successfully was it crossed that it possesses most of the good qualities of both. It won the famous Patrick Barry Medal, the committee making the following report: "Season of ripening same as Cherry and Fay. Color bright red; a good grower. Size very large, larger than Fay and Cherry, clusters very long. Productive, resembling the White Grape in this respect. Quality fine. Not so acid as Fay and other red sorts. As a table Currant, cannot be surpassed. An importing fact is that it has a long stem making it easy to pick." In addition, Perfection won highest awards at the Pan-American Exposition and a gold medal at the St. Louis World's Fair. The call for the Perfection has been so great since its introduction that there have never been enough plants to supply the demand. $\$ 3.00$ per dozen- $\$ 20.00$ per 100 .

Wilder A remarkable variety, for which we predict great popularity, both for table Wilder and market. One of the strongest growers and most productive. Bunch and berries very large bright attractive red color, even when dead ripe; hangs on bushes in fine condition for handling as late as any known variety. Compared with the celebrated Fays, is equal in size, with longer bunch better in quality, with much less acidity; ripens at same time, continues on bush much longer; fully as prolific, In some trials largely outyielding it. Strong plants. \$2.00 per dozen-\$12.00 per 100.

\section{Gooseberries}

Excellent fruits for making jellies. The bushes are hardy and vigorous. Cultivate Gooseberries the same as Currants.

Downing A very strong, vigorous grower. Healthy and free from mildew. It produces great quantities of large, pale green, tender-skinned berries of ality. It is one of the oldest and most widely grown varieties and is excellent for family use and very profitable for market. $\$ 3.00$ per dozen-\$20.00 per 100 . Houghton The berries of Houghton are smaller than Downing, but it is a strong grower, free from mildew, and particularly healthy and hardy. You $\$ 12.00$ per 100 .

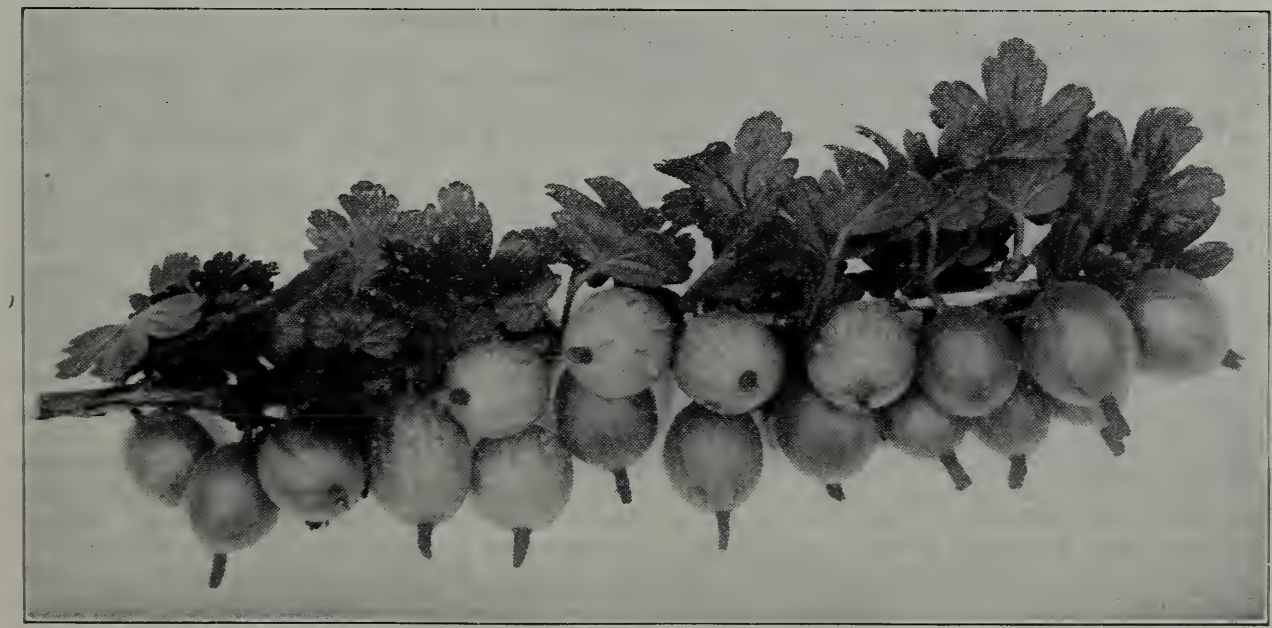

Downing. 

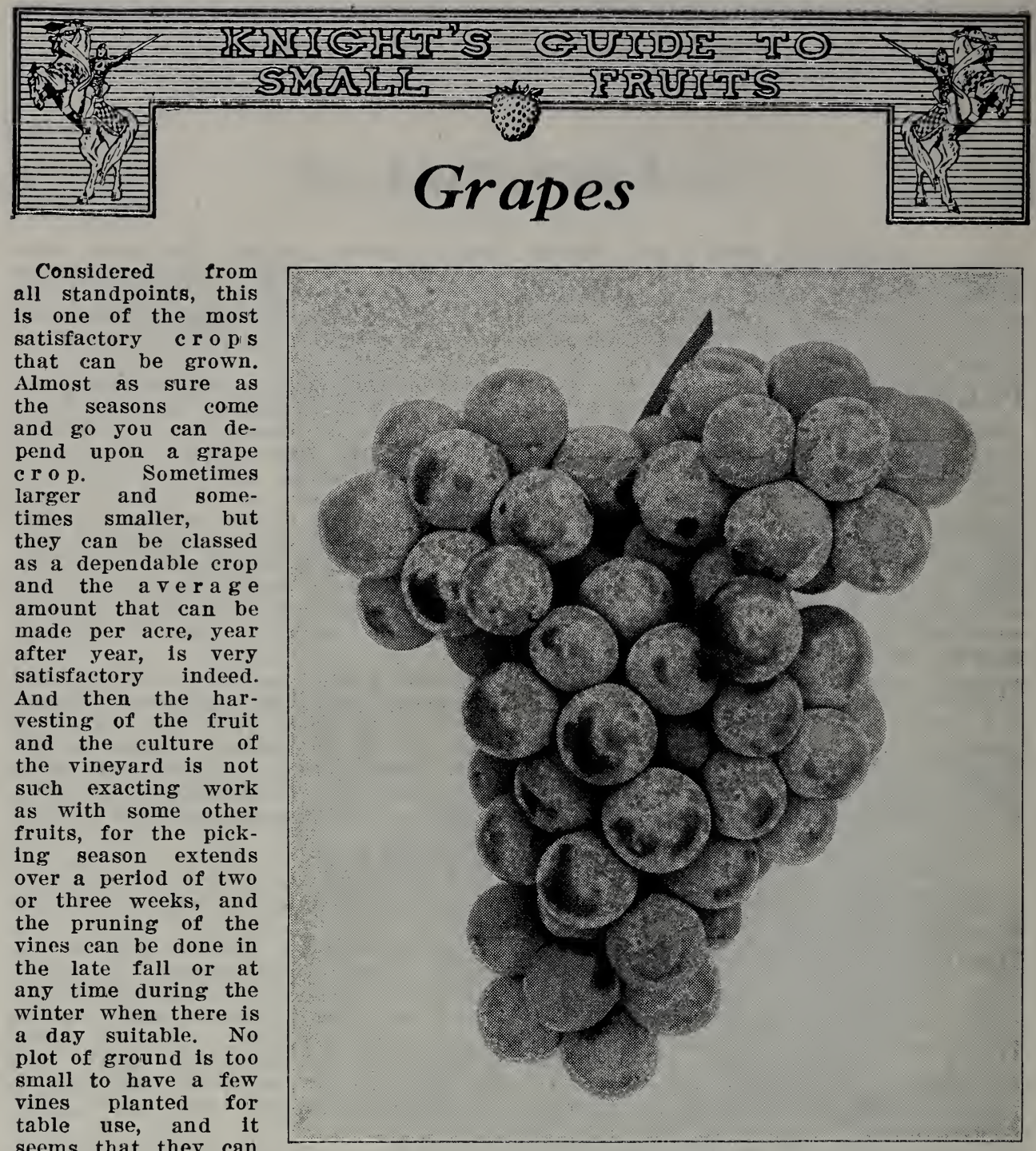

Concord.

not be planted on too large a scale for

commercial purposes. For instance, here at Sawyer and in the vicinity adjacent are located vineyards of The Lakeside Vineyard Company, comprising over 600 acres of grapes in full bearing. This is the largest vineyard under one management in this state.

Any good dry soil with sufficient drainage is suitable for growing Grapes, if the exposure and climate is favorable. Before planting, plow, harrow, and pulverize thoroughly down to a depth of 12 or 18 inches. Plant in rows 8 to 10 feet apart and the plants 10 to 12 feet in the rows. There are so many methods of pruning, different methods being adapted to different localities, that we will not dwell on that point, only to say that proper pruning is very essential to the successful growing of Grapes, and the method that is proving best in your locality is the one for you to follow.

Note.--Wonderfully big money has been made growing grapes for the past few years which creates an unusually heavy demand for plants. And the plant crop is limited so you will surely be disappointed if you do not order early.

Concord Blue. Decidedly the most popular Grape in America, and deservedly Concord so. Bunch large, compact; berries large, covered with rich bloom; skin tender, but sufficiently firm to carry to distant markets; flesh juicy, sweet, pulpy, tender; vine a strong grower, very hardy, healthy and productive. For general cultivation the most reliable and profitable variety grown. \$2.50 per dozen; \$15.00 per 100. Dear Sirs:- Dolton, Ill., May 15, 1920.

I received the plants in good condition and they are the best looking plants we ever got from any company. MRS. J. J. LEMBCKE. 


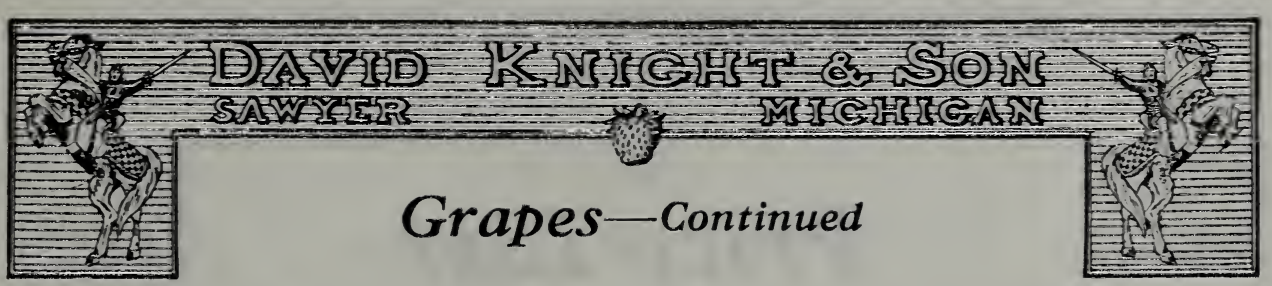

NIA G A A White. Occupies the same position among the white varleties as NIA G A A Concord among the black, the leading profitable market sort. Bunch and berries greenish white, changing to pale rellow when fully ripe. Skin thin but tough, quality much like Concord. Niagara will thrive and produce big crops almost anywhere. It does well in Michigan and south to the most southern states. Read what the experiment stations say about it:

"If restricted to one rariety, for either home or market, would choose Niagara. Other sorts are better in some particulars, but taken as a whole, there is no other its equal. Good growers, productire enough, alwars handsome in bunch and berry, of very good quality, with flaror one does not tire of. Will hang after ripening without rotting, cracking or wilting."-Illinois Experiment Station.

"Standard White Grape for home and market."-Georgia Experiment Station. \$3.50 per dozen; \$20.00 per 100 .

Moore's Early Very popular for early market. Moderate grower, healthy, and sufflently productive. $\$ 30$ per dezen; $\$ 20.00$ per 100 .

\section{Asparagus}

Asparagus will grow well in almost any soil except low, damp ground, but the land should be under good cultivation and free from weeds. Plant in trenches 10 inches deep, and 41/2 feet apart. Place plants in the trench 12 to 18 inches apart, spreading roots out flat. Then corer with 2 or 3 inches of soil, allowing shoots to come up through, and get a foot or so in height before filling the trench up level. After the first good freeze, cut off tops and burn. Then corer bed with well rotted manure; if none is arailable, apply some commercial fertilizer in the spring, which should be harrowed in before growth starts.

We hare only two rariethes that are grown largely here for the Chicago market and they are reliable.

\section{Conover's Colossal}

This good old variety is known ererywhere; is of large size, rapid growth, and of good quality. Large plants, $\$ 1.50$ per $100 ; \$ 10.00$ per 1,000 .

Palmetto A valuable rariety wideIs planted. It is larger than Conorer, fully as ear15 , and the flaror is excellent. Strong plants, $\$ 1.50$ per 100; $\$ 10.00$ per 1,000 .

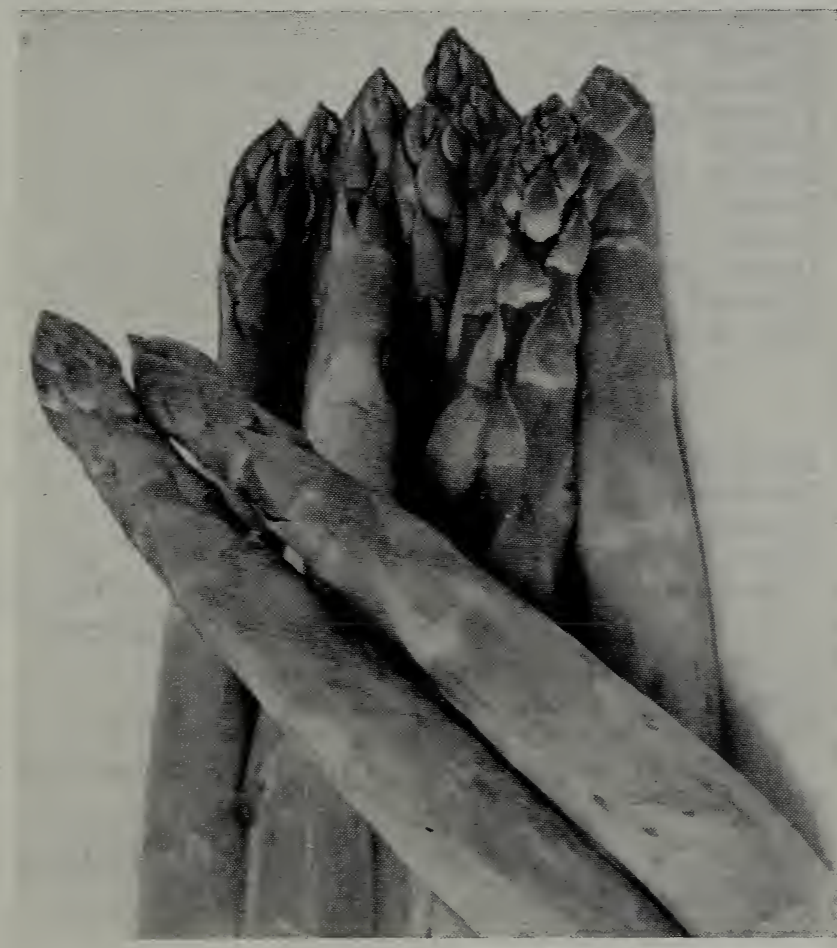

Scio, N. Y., May 11, 1920 .

Gentlemen :-

I wish to sas the strawberrs plants sou shipped me on April 30th, and which I receired on May 5 th, were in fine condition. I wish I could thank the men personalls who dug and packed those 1500 plants. I never saw such fine roots on strawberry plants. I greatly appreciate rour plants and prompt serrice. 


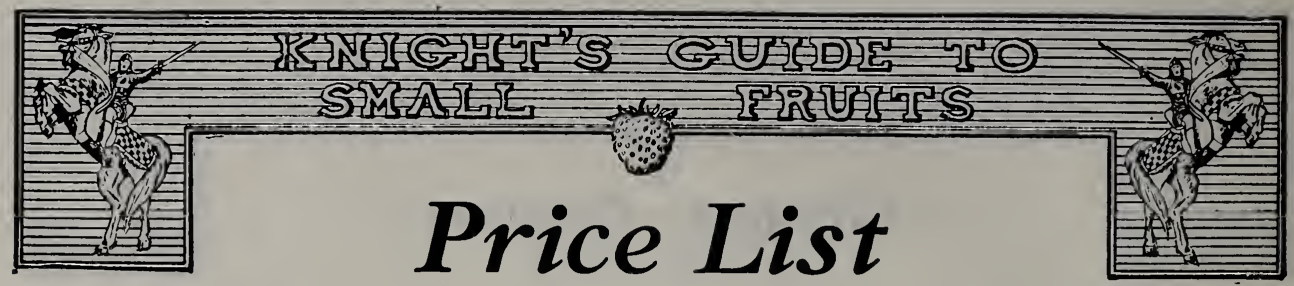

\section{Strawberry Plants}

We sell 250 of any one variety at thousand rate. 100 each of several varieties takes the hundred rate.

\section{Fall Bearing}

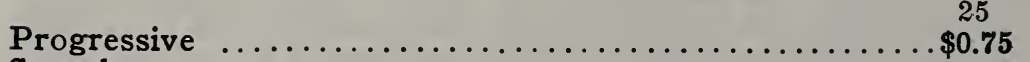

$100 \quad 1000$

Superb

\section{General List}

Aroma ...............................50

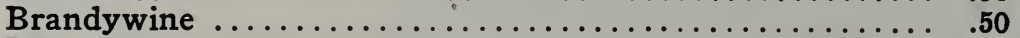

Bubach .............................. 50

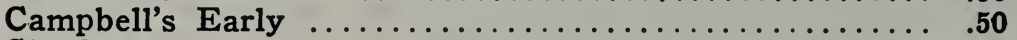

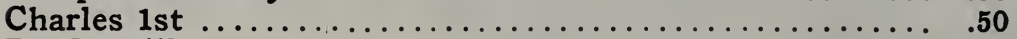

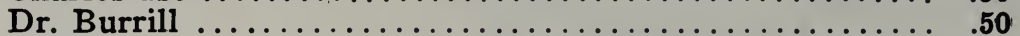

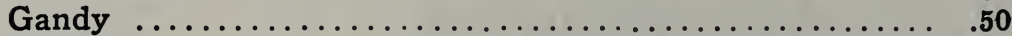

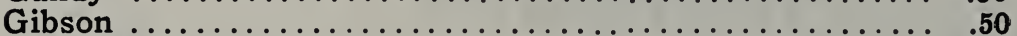

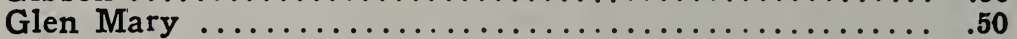

Haverland $\ldots \ldots \ldots \ldots \ldots \ldots \ldots \ldots \ldots \ldots \ldots \ldots \ldots \ldots \ldots . .50$

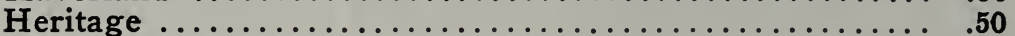

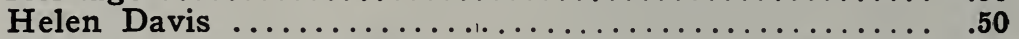

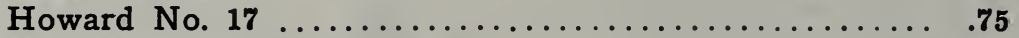

Minnesota No. 3 ............................... .50

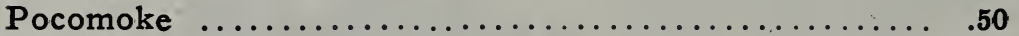

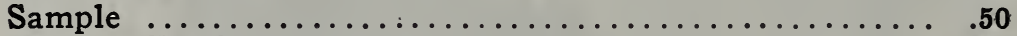

Senator Dunlap ............................ .50

Steven's Late Champion .................... $\mathbf{. 5 0}^{50}$

Teddy Roosevelt ........................... ${ }^{50}$

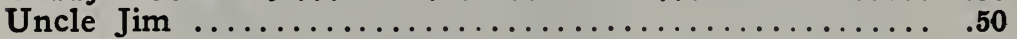

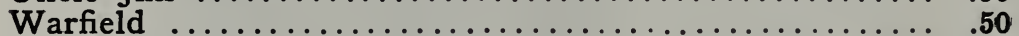

Wm. Belt . . . . . . . . .

Raspberries

Black Raspberries

Black Pearl

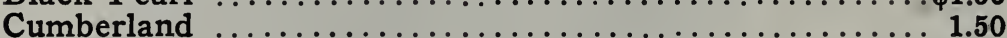

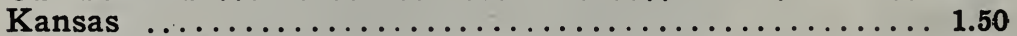

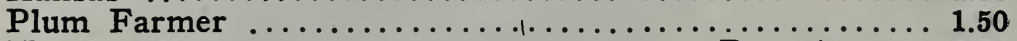

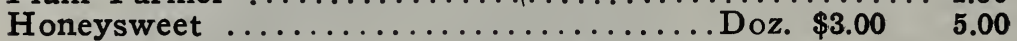

Red Raspberries

Cuthbert

King

St. Regis

Columbian

\section{Purple Raspberries}

\section{Blackberries}

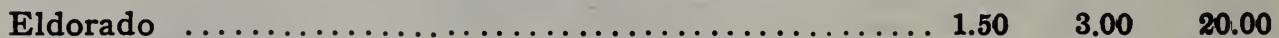

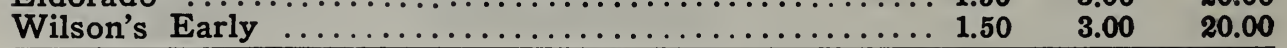

To Determine the Number of Plants Required to Set an Acre of Land

Multiply the distance in feet between the rows by the distance the plants are apart in the rows and the product will be the number of square feet for each plant or hill; which divided into the number of feet in an acre $(43,560)$ will give the number of plants required to the acre. 


\section{DAVID KNIGHT \& SON SAWYER, MICHIGAN}

Please forward to

Name.

Postoffice

County

State

Express Office

Ship by (State here how to forward)
R. F. D. No.

P. O. Box

Street

Freight Station

On or about 192 192

Please write name and address plainly, and fll all blanks perfectly. Always state how goods shall be sent, attach price to each article and add up accurately. Make all letters short and to the point, and

please do not write letters on the same sheet with the order.
QUANTITY
VARIETY OF PLANTS ORDERED
P R I C E

Dollars




\section{PLEASE USE THIS ORDER SHEET}

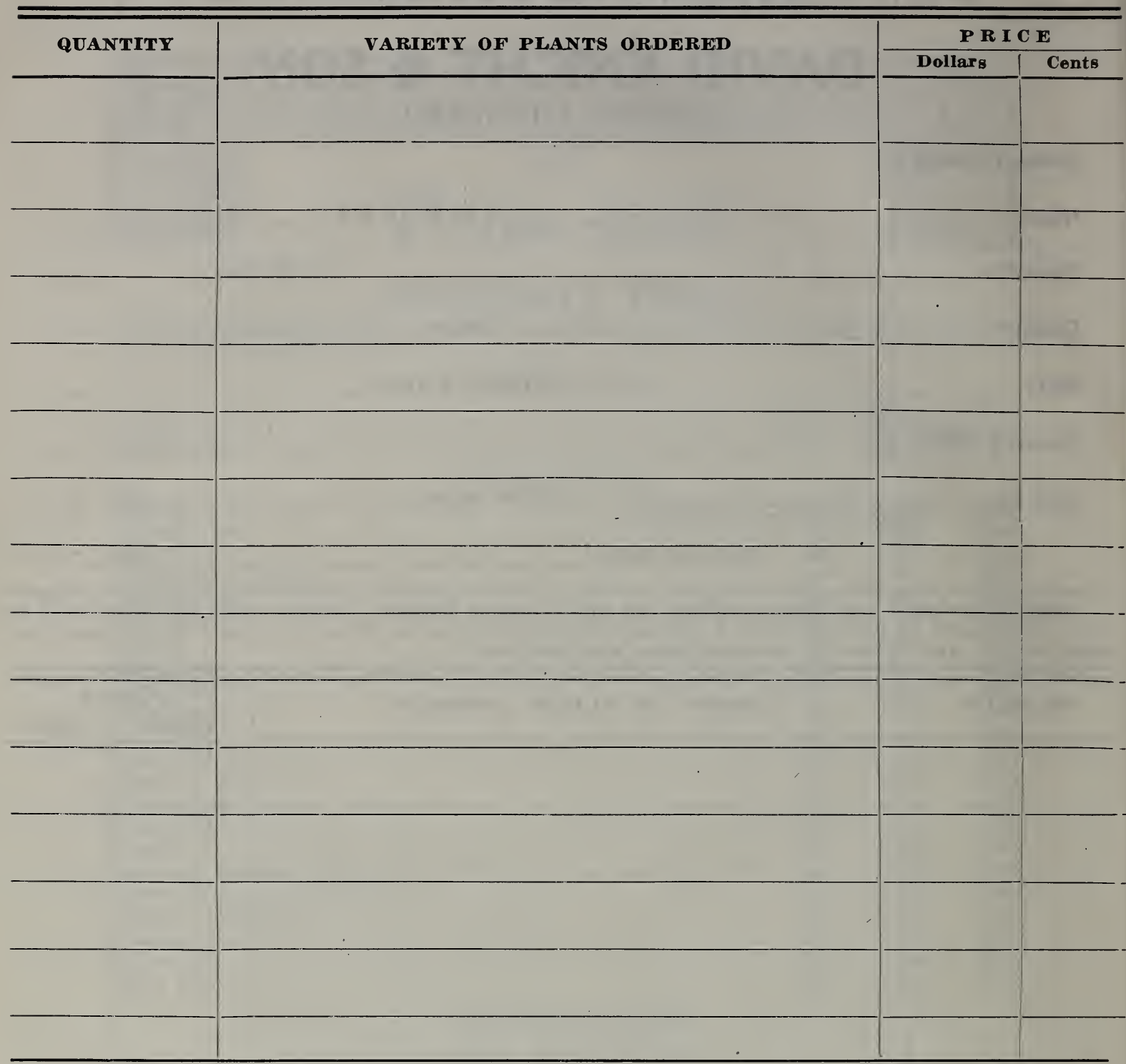

Please write the names and addresses of any acquaintances or friends who might be interested in, or buyers of small fruit plants. 


\section{The "Kant-Klog" Sprayer}

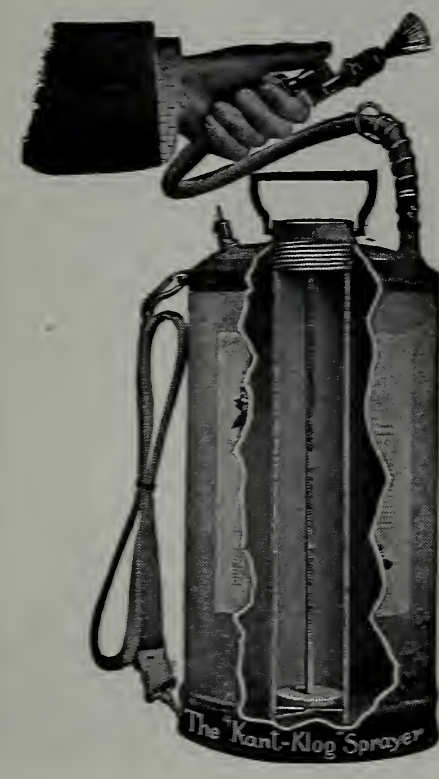

A few seconds working of the air pumpcharges the sprayer with compressed air, a powerful and elastic force, which discharges the liquid in the form of either fine sprays or solid streams as desired.

Sprays Trees, all kinds of Small Fruits, and Garden Vegetables, Disinfectants, Whitewash and many other uses.

\section{Description}

The Sprayer body is made of heavy polished brass or galvanized steel as desired. Both top and bottom are dome shaped; joined to body under heavy pressure, making a complete double seam. When completed this body is thoroughly tested at double the pressure ordinarily used, the result being that not one in a thousand give any of the troubles common with other constructions.

Hose is high grade, couplings solid brass with standard cut threads. Air pump of two inch heavy brass tubing. Fítted with "Kant-Klog" nozzle for making two round and one flat spray, two solid streams, spring hose cock, carrier strap and safety valve.

Price of Galvanized steel and above fittings..................... $\$ 8.00$

Price of Brass body and above fittings........................ 11.25

Brass pipe for tree spraying, 3 feet...........................

\section{No. 4 and No. 8}

For orchard or field spraying. Can be mounted on either end or side of an ordinary barrel, or on a tank.

Outfits of this pattern put out ten years ago are still in active use, with never a penny's expense for repairs except replacing the hose. We say frankly and honestly that we do not believe there was ever a pump on the market as free from breakage and repair troubles.

This pump has large air chamber and possesses great power and force. The churn dash agitator attached to piston thoroughly mixes the solution at every stroke of the pump handle.

We do not furnish barrels, as suitable ones on which pump is easily mounted can be secured in all localities.

At prices quoted below, each pump is fitted with five feet of hose. five feet of iron extension pipe and one "Kant-Klog" nozzle, making a splendid outfit, fully guaranteed, at a very low cost.

No. 4, price with seamless brass cylinder two and one-half inches in diameter, seven inches long, brass piston rod and brass screw

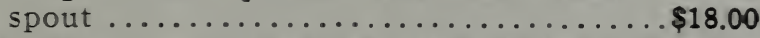
No. 8 , the same as No. 4, with all brass plunger, brass valve and valve seat............. \$21.00

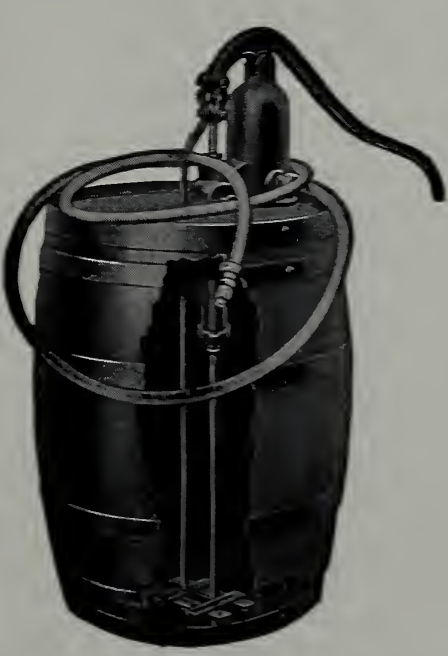

No. 4 and No. 8 
